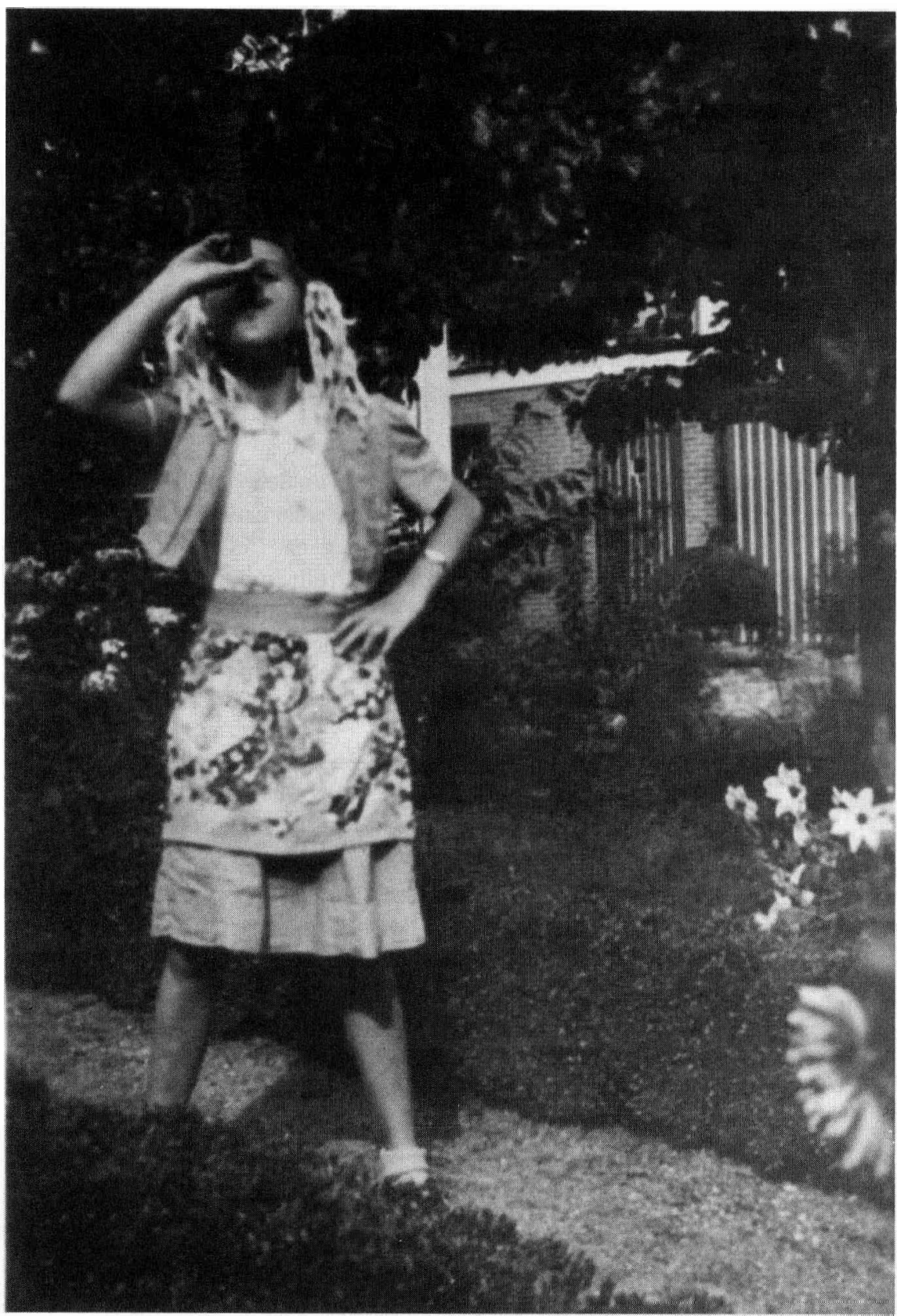

1 Annelies van der Schaten Olivier met haar nationaal feestschortje en een feesttoeter op 5 mei 1947. 


\title{
Van Indonesische urn tot Indisch monument: vijftig jaar Nederlandse herinnering aan de Tweede Wereldoorlog in Azië ${ }^{1}$
}

\author{
ELSBETH LOCHER-SCHOLTEN
}

\section{Inleiding}

Op 5 mei 1946 droeg een elfjarig meisje een klein schortje gemaakt van oude lapjes, een kindervariant van de 'Nationale feestrok'. Het idee van zo'n nationaal kledingstuk voor vrouwen was afkomstig van de Amsterdamse Mies Boissevain-van Lennep, overlevende van het concentratiekamp Ravensbrück. Gemaakt van restanten van de oude kleren van dierbaren en versierd met geborduurde herinneringen zou dat een vrouwelijke manier zijn om de Tweede Wereldoorlog te gedenken en de herinneringen te integreren ${ }^{2}$. Dit meisje had echter haar eigen ervaringen en herinneringen. Zij had de oorlogsjaren doorgebracht in een Japans interneringskamp voor burgers in Nederlands-Indië. Begin 1946 was ze gerepatrieerd naar Nederland. Trots op haar schortje nam ze dat jaar op een zeer Hollandse wijze deel aan de eerste nationale 4 en 5 mei-herdenking van na de oorlog. Niets op dat schort herinnerde haar aan Indië. '... Destijds wilden we er echt bijhoren ... En we zagen Holland als ons vaderland' ${ }^{3}$. Nu, meer dan vijftig jaar later, laat ze 5 mei aan zich voorbijgaan. Wel bezoekt ze op 15 augustus de herdenking van het einde van de oorlog in Indië bij het Indisch monument in Den Haag.

De herinnering aan de Tweede Wereldoorlog in de Pacific heeft in Nederland een eigen parcours afgelegd: van 'nationaal feest-schortje' tot bronzen beelden, van mei naar augustus, van assimilatie aan de Nederlandse oorlogsherinnering tot de manifestatie van een eigen Indische identiteit. Die veranderingen hebben zich namelijk niet tot dit meisje beperkt. Herinneringen zijn zelden louter individueel bepaald. Beelden van en ideeën over het verleden die in de maatschappij circuleren, inspireren persoonlijke herinneringen en stroomlijnen die tot sociale activiteiten en rituelen, tot monumenten en andere herinneringstekens ${ }^{4}$.

1 Dit artikel is een bewerking van een Engelstalige bijdrage die ik in 1995 schreef voor het congres 'Memories of the Second World War in international comparative perspective' (RIOD, Amsterdam). Sindsdien verschenen literatuur is in de annotatie verwerkt. Ik ben de betrokkenen bij de Indische monumenten, die ik indertijd heb mogen interviewen zeer erkentelijk voor hun bereidheid mij in hun kennis over dit onderwerp te laten delen: A. A. (Harry) Verheij (interview 7 februari 1995); mevrouw J. van Kempen (8 februari 1995), D. van Loghem (22 februari 1995), en P. S. J. van de Ven (21 maart 1995). Dr. Jolande Withuis, dr. Petra Groen and dr. Penny Summerfield gaven hun commentaar op een eerdere versie van dit artikel, waarvoor ik hen hartelijk dank.

2 J. Withuis, De jurk van de kosmonaute. Over politiek, cultuur en psyche (Amsterdam, Meppel, 1995) 60-84.

3 J. Withuis, "In de lappenmanden van de vrouwen leeft het verleden van een volk'. Een keuze uit de rokken', 'De Nationale feestrok', Opzij, Bijlage catalogus tentoonstelling Rijksmuseum (mei 1995) 15.

4 A. de Swaan, 'De maatschappelijke verwerking van oorlogsverledens', in: J. Dane, ed., Keerzij van de bevrijding (Deventer, 1984) 54. 
In deze bijdrage verken ik de geschiedenis van de publieke herinnering in Nederland aan de Tweede Wereldoorlog in het voormalig Nederlands-Indië aan de hand van een aantal monumenten. Als sociale en politieke constructies worden monumenten geladen met interpretaties van het verleden, die aan dat verleden op hun beurt samenhang, zin en betekenis geven. Hun ontstaansgeschiedenis maakt dan ook de consensus en strijd over die interpretatie van het verleden zichtbaar ${ }^{5}$. Zij laat eveneens de daarbij horende in- en uitsluitingsmechanismen zien: wie herinnert wie en wat, wie en wat wordt buiten de deur gehouden?

Bovendien dienen monumenten bij herdenkingen als verzamelpunten en als centra voor de zichtbaarheid van betrokken groeperingen. Daardoor versterken zij de groepsidentiteit. Of, zoals Pierre Nora het heeft gesteld, monumenten kunnen dienen als lieux de mémoire en zo nationale identiteit definiëren, nu het publiek volgens hem het contact met het verleden zelf verloren lijkt te hebben. Zoals we zullen zien, beantwoorden de Indische oorlogsmonumenten aan deze behoefte aan een zichtbare identiteit, zij het die van een specifieke groep binnen de natie en niet van de natie als geheel.

In 1980 waren er in Nederland rond de 1.500 monumenten opgericht ter herinnering aan de Tweede Wereldoorlog ${ }^{6}$. Sindsdien is er een aanzienlijk aantal bij gekomen. Tot het eind van de jaren tachtig konden Indische herdenkingsplaatsen evenwel op de vingers van één hand geteld worden. Om het herinneringsproces aan de oorlog in Indië aanschouwelijk te maken koos ik daar drie van.

1 het Nationaal monument op de Dam (Amsterdam), dat de Twaalfde of Indonesische urn bevat (1956);

2 het 'Vrouwenmonument', oorspronkelijk in Apeldoorn (1971), nu in het park van het museum en conferentiecentrum 'Bronbeek' (Arnhem);

3 het Indische monument in Den Haag (1988).

Deze staan hier niet alleen centraal omdat zij van nationaal belang zijn, maar ook omdat zij elk een specifieke periode in de Indische oorlogsherinnering vertegenwoordigen. Want de Indische oorlogsherinneringen volgen - zij het met een lichte vertraging — algemene trends in de herinnering aan de oorlog in Nederland: een levendige belangstelling onmiddellijk na de oorlog, die aan het einde van de jaren veertig en in de jaren vijftig afnam, in de jaren zestig herleefde en tot onverwachte hoogte steeg in de jaren tachtig en negentig van de twintigste eeuw.

De Indische oorlogsherinneringen hebben echter ook een eigen dynamiek, omdat zij diepgaand beïnvloed zijn door het dekolonisatieproces van 1945-1949. Deze periode werd aanvankelijk zelfs als onlosmakelijk onderdeel van de oorlog in de Pacific beschouwd $^{7}$. De problemen rond de Indische oorlogsherinneringen in Nederland waren

5 J. E. Young, The texture of memory. Holocaust memorials and meaning (New Haven, Londen, 1993) 302. J. Bodnar, Remaking America. Public memory, commemoration and patriotism in the Twentieth Century (Princeton, New Jersey, 1992).

6 W. Ramaker, B. van Bohemen, Sta een ogenblik stil... Monumentenboek 194011945 (Kampen, 1980).

7 C. Fasseur, 'Het verleden tot last. Nederland, de Tweede Wereldoorlog en de dekolonisatie van Indonesië', in: D. Barnouw, e. a., 1940-194S: Onverwerkt verleden? Lezingen van het symposium georganiseerd door het Rijksinstituut voor Oorlogsdocumentatie, 7 en 8 mei 1985 (Utrecht, 1985) 133155. 
enerzijds een direct gevolg van fysieke afstand - een oorlog uitgevochten aan de andere kant van de aardbol - , anderzijds van het moeizame dekolonisatieproces. Die politieke kwestie verhinderde een nationale consensus over in Indië ondergane oorlogservaringen. Dat die Indische oorlogsherinneringen zich in de afgelopen vijftig jaar toch een plaats hebben verworven in de Nederlandse cultuur en politiek, was te danken aan drie sociaal-culturele processen: een 'depolitisering' van de oorlogsherinnering ten gevolge van de scheiding tussen de periode 1941 -1945 en de periode 19451949; een groeiende erkenning in Nederland van gedeeld slachtofferschap dankzij de 'psychologisering' van de oorlogservaringen; en de emancipatie van de Indische groeperingen zelf.

\section{Tegengestelde interessesferen}

Voor de gemiddelde Nederlander was de oorlog in Indië een 'verre oorlog' geweest. Tijdens de bezetting had Indië nauwelijks de aandacht getrokken. Tot maart $1942 \mathrm{had}$ de nationale trots zich nog kunnen verheugen over de laatste onafhankelijke resten van het Nederlandse rijk overzee. Daarna hadden het totale gebrek aan communicatie en de zorg om het dagelijks brood de archipel uit het Nederlandse blikveld doen verdwijnen. De Japanse bezetter wist Indië volledig van de buitenwereld te isoleren. Informatie over internering van krijgsgevangenen en burgers, over dwangarbeid en over honger en ellende van Indonesiërs, Chinezen en Indo-europeanen buiten de kampen drong nauwelijks tot Nederland door ${ }^{8}$. De meeste Nederlanders bood de oorlog tegen Japan dan ook weinig concrete punten van herkenning. Het was hoogstens een Asmogendheid, die evenals Duitsland verslagen diende te worden. Daarvoor gaven zich dan ook duizenden vrijwilligers op in het bevrijde Zuiden.

De aankomst van gerepatrieerden uit Indië na 1945 riep ook geen oude herinneringen aan rijksdelen overzee wakker. Nederland leefde op de bon en zat niet te wachten op hen die terugkeerden, of het nu oorlogsveteranen, joodse landgenoten, dwangarbeiders of mensen uit Indië waren.

Dit totale gebrek aan kennis en belangstelling stond in schril contrast tot de nationale of nationalistische gevoelens van de Europese bevolkingsgroep in Indië. In de jaren dertig had deze zich in toenemende mate met het moederland geïdentificeerd. Tussen mei 1940 en de capitulatie in maart 1942 was de oorlog in Europa in de Indische kranten zelfs geregeld voorpagina-nieuws geweest. Terwijl de Europese bevolkingsgroep in Indië dus goed geïnformeerd was over Nederland in het begin van de oorlog en haar belangstelling ook tijdens de internering had behouden, wist de Nederlandse bevolking weinig tot niets over de oorlog in Indië; een pijnlijk contrast voor hen die terugkeerden.

De capitulatie van Japan en de Indonesische onafhankelijkheidsverklaring stimuleerden de belangstelling voor de oorlog in Indië al evenmin. Zij vormden het begin van een viereneenhalf jaar durende periode van diplomatiek overleg, conferenties en guerrilla-oorlog. Het vertrek van Nederlandse dienstplichtigen — er zouden er 
95.000 gaan — verdeelde de publieke opinie: volgens een opiniepeiling van 1946 was $40 \%$ van de Nederlandse bevolking voor, $40 \%$ tegen uitzending ${ }^{9}$. In de zomer van 1947 verdeelde de eerste Politionele Actie met name de PvdA. Na die actie beschouwde de grote meerderheid van de Nederlandse bevolking de oplossing van de 'Indonesische kwestie' als de belangrijke taak van de regering ${ }^{10}$. Beide aspecten, een Nederlands gebrek aan belangstelling en deze pijnlijke ervaringen, bepaalden het gebrek aan ruimte voor Indische oorlogsherinneringen in Nederland, zoals de geschiedenis van de Twaalfde of Indonesische urn in het Nationaal monument op de Dam aangeeft.

\section{DE INDONESISCHE URN IN HET NATIONAAL MONUMENT}

\section{Monumenten in het naoorlogse Nederland}

(Oorlogs)herinneringen blijken in het algemeen een hoog ik-gehalte te kennen: elke groep herinnert zich in de eerste plaats de eigen lotgevallen, zoals uit Amerikaans onderzoek is gebleken ${ }^{11}$. Het merendeel van de oorlogsmonumenten was dan ook een initiatief van direct betrokkenen. Nederland had evenwel door zijn lange traditie van neutraliteit geen enkele ervaring op dit gebied. Hier - anders dan in Frankrijk en Groot-Brittannië - geen monument voor de onbekende soldaat, geen eeuwige vlam, geen steen met de namen van de voor het vaderland gevallenen in dorp of stad.

Toen na mei 1945 particulieren en gemeenten zich opmaakten om in die lacune te voorzien, greep de Nederlandse regering onmiddellijk in. Vanaf oktober 1945 stelde zij goedkeuring voor plaatselijke monumenten van overheidswege verplicht. Eenjaar later werd een Nationale Monumenten Commissie (NMC) geïnstalleerd met de taak om de regering over de oprichting van nationale oorlogsmonumenten te adviseren. De NMC vormde een eerbiedwaardig gezelschap. Zij bestond uit ministers, generaals, commissarissen van de koningin, burgemeesters, vertegenwoordigers van kerken, universiteiten, studentenorganisaties, verzet en illegaliteit, vrouwenorganisaties, kunstenaars, vakbonden, de media, etc. De NMC illustreerde daarmee de door de regering gestimuleerde behoefte in Nederland aan nationale consensus waar het de oorlog betrof; een van de resultaten van diezelfde oorlog ${ }^{12}$.

Die drang tot eenheid kende echter territoriale grenzen: zij bleef beperkt tot het Europese deel van het rijk, de elf provincies van Nederland. Een officiële vertegenwoordiging van de West en de Oost ontbrak. Toen in november 1947 de NMC haar plannen voor negen nationale monumenten ontvouwde, was er geen enkele gewijd aan de oorlog in de Pacific ${ }^{13}$.

9 Veteranen. Een nieuwe dialoog met overheid en samenleving. Rapport van de Commissie maatschappelijke erkenning veteranen (Den Haag, januari 1991) 7.

10 J. C. H. Blom, Crisis, bezetting en herstel. Tien studies over Nederland 1930-1950 (Rotterdam, 1989) 184-217, 187.

11 Young, Texture, 49, 67.

12 F. van Vree, In de schaduw van Auschwitz. Herinneringen, beelden, geschiedenis (Groningen, 1995) 30-31,49, 175.

13 Ramaker, Van Bohemen, Sta een ogenblik stil, 23,69. 
Het belangrijkste monument zou het Nationaal monument op de Dam worden. Plannen daarvoor hadden al in de zomer van 1947 de officiële goedkeuring verworven. Omdat het ontwerp en de bouw van een definitief monument de nodige tijd zouden vragen werd in december 1947 een voorlopig monument opgericht. Het bestond uit een halve boog van bakstenen zuilen, waarin elf urnen waren opgeslagen, gevuld met aarde van executieplaatsen in de elf provincies. Ook deze umen symboliseerden nationale eenheid in een territoriaal beperkte $\mathrm{zin}^{14}$. Bij de onthulling werd de strijd in Japan zelfs niet genoemd. De NMC, de plannen voor nationale monumenten en het tijdelijk monument zelf waren alle uitsluitend op Nederland gericht. In 1947 werden de herinneringen aan de oorlog in de Pacific uit het nationale geheugen gefilterd. Dankzij de uit Indië gerepatrieerden zelf kwam hierin verandering.

\section{Het debat over de Twaalfde of Indonesische urn}

Reeds in het najaar van 1947, nog vóór de onthulling van het voorlopige monument, was het werkcomité van de NMC onder druk van Indische zijde komen te staan. Dit werkcomité, verantwoordelijk voor de oprichting van het tijdelijk monument op de Dam, bestond uit een aantal leden uit het verzet. Getuige de beknopte notulen van zijn vergaderingen was het unaniem in zijn kritische benadering van het koloniale beleid. In oktober 1947 - de Eerste Politionele Actie was toen enkele maanden achter de rug - had het bewust voor een opzet 'in de meest volstrekt Nederlandsche zin' gekozen $^{15}$. Eind 1947 groeide de Indische ontevredenheid. Het ministerie van Overzeese Gebiedsdelen, hoge militairen zoals admiraal C. E. L. Helfrich en de Nederlands-Indische Bond van Ex-Krijgsgevangenen en Geïnterneerden (NIBEG) vroegen aandacht voor de vergeten groep. De NIBEG was in het najaar van 1945 opgericht en telde eind 1947 al 20.000 leden in Nederland, voornamelijk afkomstig uit de in Nederland geboren koloniale elite (totok). Men wenste erkenning van de in Indië geleverde oorlogsinspaningen en een waardige herdenking van de aldaar gevallenen; dit niet door oprichting van een Indisch monument maar door opname van een urn uit Indië in het monument op de Dam. Het werkcomité liet zich niet direct overtuigen ${ }^{16}$.

Gezien de eerder gekozen symboliek van nationale eenheid was het inderdaad een netelig politiek probleem. Kon men op dat moment van diplomatiek overleg en militaire strijd wel van eenheid tussen moederland en kolonie spreken? Een urn met aarde van begraafplaatsen in Indië riep vragen op over het gebruik van Indonesische aarde in dit verband. Mocht men daarover wel beschikken of diende men daarbij de Indonesische bevolking in te schakelen? Deze had echter tegen de Japanners gevochten maar daar ook mee samengewerkt. Hoe dus een Indonesisch initiatief te organiseren zonder dat de urn strijdpunt zou worden tussen gematigde federalisten en republikeinen? En

14 D. Carasso, 'Het Nationaal monument op de Dam en zijn beelden', in: M. Jonker, e. a., In beeld gebracht. Beeldhouwkunst uit de collectie van het Amsterdams Historisch Museum (Zwolle, 1995) 133 $147,134-135$.

15 Notulen werkcomité van de Nationale Monumenten Commissie 25-10-1947, Gemeentearchief Amsterdam (GAA) 396, map 2. Carasso, 'Nationaal monument', 135.

16 Notulen werkcomité 31-1-1948, GAA 396, map 2. 
bovendien: welke plaats zouden degenen die op dat moment vielen hierbij moeten innemen? Uit deze vragen blijkt wel, dat het hierbij niet alleen ging om een stijlvolle herdenking van oorlogsslachtoffers.

In november 1947 had het werkcomité in principe al besloten tot 'opname van alle mensen en groepen uit alle phasen van de strijd over de periode van 1940-1945 ', ook van slachtoffers uit Indië. De categorie van slachtoffers 'die nu dagelijks in Indië vallen' wees het echter beslist af ${ }^{17}$. Begin 1948 — kort nadat beide partijen in Indië via de Renville-overeenkomst tot overeenstemming over een bestand en een interimbewind waren gekomen — stelde de voorzitter van het werkcomité tegenover de minister, dat het monument in geen geval in opspraak mocht raken. Nederlanders in Indië konden zijns inziens niet als enigen over de Indonesische grond beschikken. Daarom moest de medewerking van de inheemse bevolking verkregen worden. Anders zou een Nederlands initiatief tot transport van aarde uit Indië als symbool van kolonialisme en als een 'politieke demonstratie' geïnterpreteerd kunnen worden. Het werkcomité vroeg dan ook om een initiatief ter plekke van alle bevolkingsgroepen, speciaal van Indonesiërs. Nederlanders zouden terughouding dienen te betrachten. Het werkcomité plaatste zijn herdenkingsbeleid dus in een kader van federalisme en samenwerking tussen Nederlanders en Indonesiërs, met een hoofdrol voor de laatsten. Daarmee vertaalde het zijn wensen betreffende de politieke verhoudingen in een passende symboliek van herinneren ${ }^{18}$.

Het werkcomité, opgelucht dat het zich 'uit dit wespennest' had weten te bevrijden, wist in januari 1948 de zaak aan het ministerie te delegeren. Een maand later bracht de minister van Overzeese Gebiedsdelen, J. A. Jonkman, het idee van een herdenkingsurn onder de aandacht van de Indische regering en de gouverneurs van Suriname en de Nederlandse Antillen ${ }^{19}$. Allen reageerden positief, maar alleen in Indië kreeg de suggestie dankzij het optreden van generaal S.H. Spoor en de Legergravendienst ook vorm en inhoud ${ }^{20}$. De urn zou gevuld worden met aarde van 22 erebegraafplaatsen uit verschillende delen van de $\operatorname{archipel}^{21}$. Het realiseren van dat plan had echter meer voeten in de aarde. Pas in april 1949, lang na de Tweede Politionele Actie van december 1948/januari 1949, kon de Legergravendienst beschikken over een urn die speciaal voor dit doel vervaardigd was. En toen pas consulteerde de dienst de regionale autoriteiten, zowel de Nederlandse als de Indonesische federalisten, over dit project. Enkele kritische opmerkingen vanuit de meest ontwikkelde deelstaat Oost-Indonesië leidden

17 Notulen 15-11-1947, GAA 396, mappen 1 en 2.

18 Van Holthe tot Echten aan A. van Velsen, Culturele Contacten, 31-1-1948; 'Nota betreffende de belangen van het Nederlands Indisch verzet, in verband met de actie der Nationale Monumenten Commissie', 28-21948; 'Nota H. M van de Poll', 9-2-1948, alle in archief ministerie Overzeese Gebiedsdelen (MINOG), dossier, nr. 323, Algemeen Rijksarchief (ARA), Den Haag.

19 Zie verbaal 20-2-1948, no. 23 en no. 24, MINOG dossier 323, ARA.

20 Zie voor een uitgebreider weergave van de gang van zaken rond de urn in Indië E. Locher-Scholten, 'De strijd om de Indonesische urn. De Nederlandse herinnering aan de Tweede Wereldoorlog in Azië', in: W. Willems, J. de Moor, Hel einde van Indië. Indische Nederlanders tijdens de Japanse bezetting en de dekolonisatie (Den Haag, 1995) 267-278.

21 Spoor aan luitenant-gouvemeur-generaal, 18-5-1948, archief Algemene Secretarie Batavia, inv. nr. 2273, ARA. 
tot een naamsverandering. De Twaalfde urn werd omgedoopt in Indonesische um, dit om associatie met de conservatieve, Nederlands gezinde beweging voor een Twaalfde provincie in de Minahasa (Twapro) te voorkomen ${ }^{22}$.

In Nederland had intussen een Voorlopige Urncommissie, bestaande uit ambtenaren en vertegenwoordigers van particuliere organisaties, een positief rapport uitgebracht aan de ministerraad. Daarin waren de politieke connotaties van het plan nog eens volmondig erkend: de um was 'in het vaarwater van de Regeringspolitiek ten aanzien van de reconstructie van het Rijk' gekomen ${ }^{23}$.

Premier Willem Drees had het niet beter kunnen verwoorden. Hij was het er geheel mee eens, zozeer zelfs dat hij in mei 1949 zijn medewerking aan het project weigerde. Voor het eerst sprak hij zich over dit project uit. Hij had daarmee gewacht totdat een oplossing van de Indonesische kwestie in zicht was. Nu de Van Roijen-Roem-overeenkomst met de belofte van een Ronde Tafel Conferentie en spoedige soevereiniteitsoverdracht begin mei was gesloten, leek dat moment aangebroken. Drees was duidelijk: hij wilde het project uitstellen of liever nog stoppen. Het zou immers onmogelijk zijn om in Indonesië zoals het gebied sinds de grondwetswijziging van 1948 heette, een Urncomissie samen te stellen, waarin alle bevolkingsgroepen gelijkelijk vertegenwoordigd zouden zijn. Bovendien zou bijzetting van een um moeilijkheden geven, omdat het niet alleen ging om een eerbewijs voor een onbekende strijder, maar om Indonesische grond en dat mede als herinnering aan de strijd na de capitulatie ${ }^{24}$. Maar zelfs de minister-president kon deze rijdende trein niet meer stoppen: de druk van het ministerie van Overzeese Gebiedsdelen en de Indische regering was te sterk. Drees slaagde er alleen in het tempo te vertragen. Begin juli 1949 besloot de Nederlandse regering tot overbrenging van de um, maar pas na afronding van de RTC. Toen dat moment in het najaar van 1949 bereikt was, stelde zij de ceremonie opnieuw uit tot na de soevereiniteitsoverdracht, omdat het kabinet bang was voor politieke demonstraties van rechtse groeperingen. Het wilde graag verschoond blijven van perscommentaren over 'de begrafenis van het Koninkrijk'

\section{Overdracht van de Indonesische urn en bijzetting in het monument op de Dam}

Op het laatste nippertje, op 13 december 1949, besloot de regering echter toch tot transport van de urn. De tekst van de oorkonde, die bij de urn behoorde, vermeldde immers dat deze door de Hoge Vertegenwoordiger van de Kroon aan koningin Juliana werd aangeboden, een formule die na de soevereiniteitsoverdracht minder betekenis zou hebben. Op 21 december 1949, zes dagen voor het vertrek van de Hoge Vertegenwoordiger, A. H. J. Lovink, vond in Batavia een officiële ceremonie plaats, bijgewoond door Nederlandse autoriteiten, vertegenwoordigers van Nederlandse organisaties in

22 Wnd. eerste regeringssecretaris aan adjudant-generaal Legergravendienst, 22-8-1949 met bijlagen, Algemene Secretarie, 2273, ARA.

23 Verslag Voorlopige Commissie Plaatsing Urnen Overzeese Gebiedsdelen (zoals de voorlopige Urncommissie voluit heette, E. L.-S.) 19-2-1949, MINOG dossier 323.

24 Minister-president Drees aan minister Overzeese Gebiedsdelen, 24-5-1949, no. 23652; notulen ministerraad 30-5-1949, beide in MINOG dossier 323.

25 Minuut verbaal 24-11-1949 Q 72, MINOG Kabt. dossier G 323. 
Indië, één Chinees en één Indonesiër, een niet geheel representatieve afschaduwing van de verschillende bevolkingsgroepe ${ }^{26}$. De urn, geplaatst in een tabernakel van sonohout, was 'van Amerikaans fabrikaat en afkomstig uit Yokohama (Japan) ${ }^{27}$. Geheel volgens plan bevatte zij aarde van de 22 erebegraafplaatsen uit de archipel. Daardoor waren ook de gevallenen uit de periode 1945-1949 opgenomen, maar dat was alleen duidelijk voor degenen die het wisten. Dit gevoelige punt werd niet expliciet benoemd $\mathrm{d}^{28}$. De begeleidende oorkonde vermeldde dat de urn

symbool [was] van de opofferingsgezindheid van allen..., zowel burgers als krijgslieden zonder onderscheid van ras of landaard, die vielen in de strijd tegen Japan en voor vrede en recht ${ }^{29}$.

Die laatste termen verwezen na de naoorlogse poging tot herstel van de orde in de kolonie; de deksel van de urn vermeldde echter alleen de jaartallen 1941-1945.

Als een vroeg kerstgeschenk arriveerde de urn op 24 december 1949 op Schiphol. Eind april 1950 werd zij bij een officiële plechtigheid in bijzijn van koningin Juliana en prins Bernhard in een half uitgegraven keldertje in het midden van het tijdelijk monument op de Dam geplaatst ${ }^{30}$. De oorspronkelijke eenheidssymboliek had afgedaan, de soevereiniteitsoverdracht had de urn gereduceerd tot symbool van ondergaan oorlogsleed $^{31}$. Tijdens de bijzettingsceremonie werd over de jaren 1945-1949 gezwegen, zo ook over het Indonesische aandeel in de strijd; dit ondanks het eerder vermelde '...zonder onderscheid naar ras of landaard ${ }^{132}$. Een Indonesische vertegenwoordiging ontbrak. Door een misverstand was de Indonesische Hoge Commissaris niet uitgenodigd, waarvoor de minister later zijn verontschuldigingen aanbood ${ }^{33}$.

De onthulling van het officiële monument op de Dam in mei 1956 voltooide de integratie van oorlogsherinneringen uit de Pacific in de Nederlandse herinneringscultuur van de Tweede Wereldoorlog. Dat gebeurde op een moment dat de NederlandsIndonesische betrekkingen zich na de opzegging van de Unie door Indonesië in januari van dat jaar op een dieptepunt bevonden ${ }^{34}$. Bij de onthulling benoemde premier Drees de teloorgegane hoop op een vrijwillige samenwerking tussen Nederland en Indonesië

26 Minuut verbaal 13-12-1949 Z 76 MINOG Kabt. dossier G323. De tekst van de oorkonde was gaandeweg ontdaan van alle politiek gevoelige retoriek. Zie voor een overzicht van de debatten hierover bijlagen bij eerste regeringssecretaris 27-10-1949, Algemene Secretarie 2273; Locher-Scholten, 'Strijd', 273-274.

27 Deze herkomst werd nergens anders vermeld, wellicht wegens het politiek gevoelige karakter ervan. Zie A. Doup, Legergravendienst II F, aan commandant leger in Indonesië, 11-2-1949, Algemene Secretarie 2273.

28 Nota Van Velsen voor minister OG, 10-6-1949, MINOG dossier 323.

29 Voor de tekst van de oorkonde zie noot 26.

30 Nibeg-orgaan, V (13 januari 1950) i, 4-5. Voor een beschrijving van urn, kistje en oorkonde zie ook MINOG dossier 323 en Algemene Secretarie 2273. Het Dam-monument was ontworpen door de beeldhouwer John Raedecker en de architect J. J. P. Oud.

31 Dat stond ook te lezen op de bronzen plaquette: 'Ter nagedachtenis van alle gevallenen in de strijd in Z. O. Azië'. Zie voor het ontwerp MINOG dossier 323.

32 Voor de teksten van de redevoeringen MINOG dossier 323.

33 Nibeg-orgaan, V (12 mei 1950) ix, 138.

34 H. Meijer, Den Haag-Djakarta. De Nederlands-Indonesische betrekkingen 1950-1962 (Utrecht, 1994). 


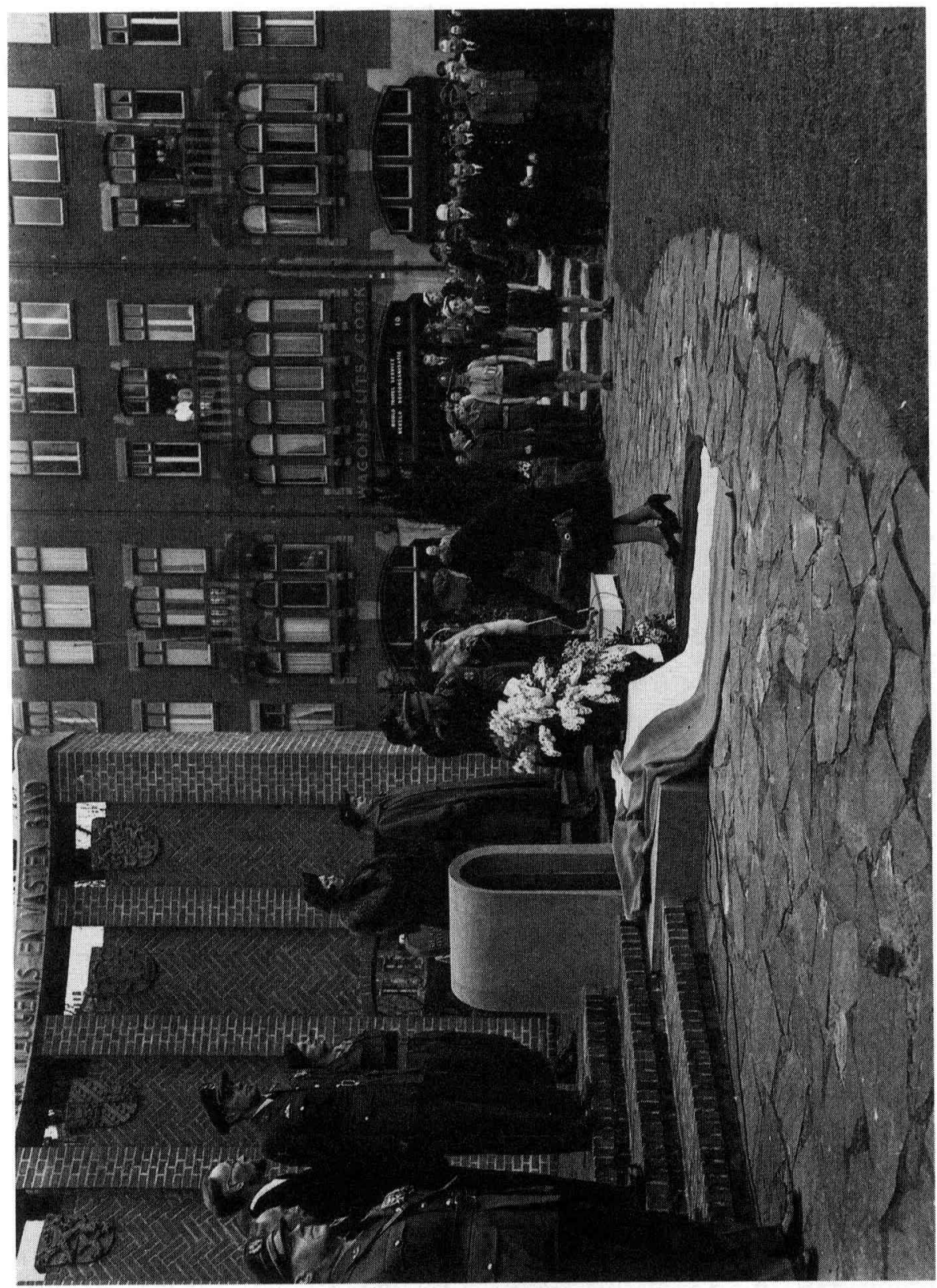

2 Kranslegging door koningin Juliana en prins Bernhard tijdens de bijzetting van de Indonesische urn in het voorlopig Nationaal monument op de Dam (29 april 1950). (Foto: Nationaal Fotopersbureau) 


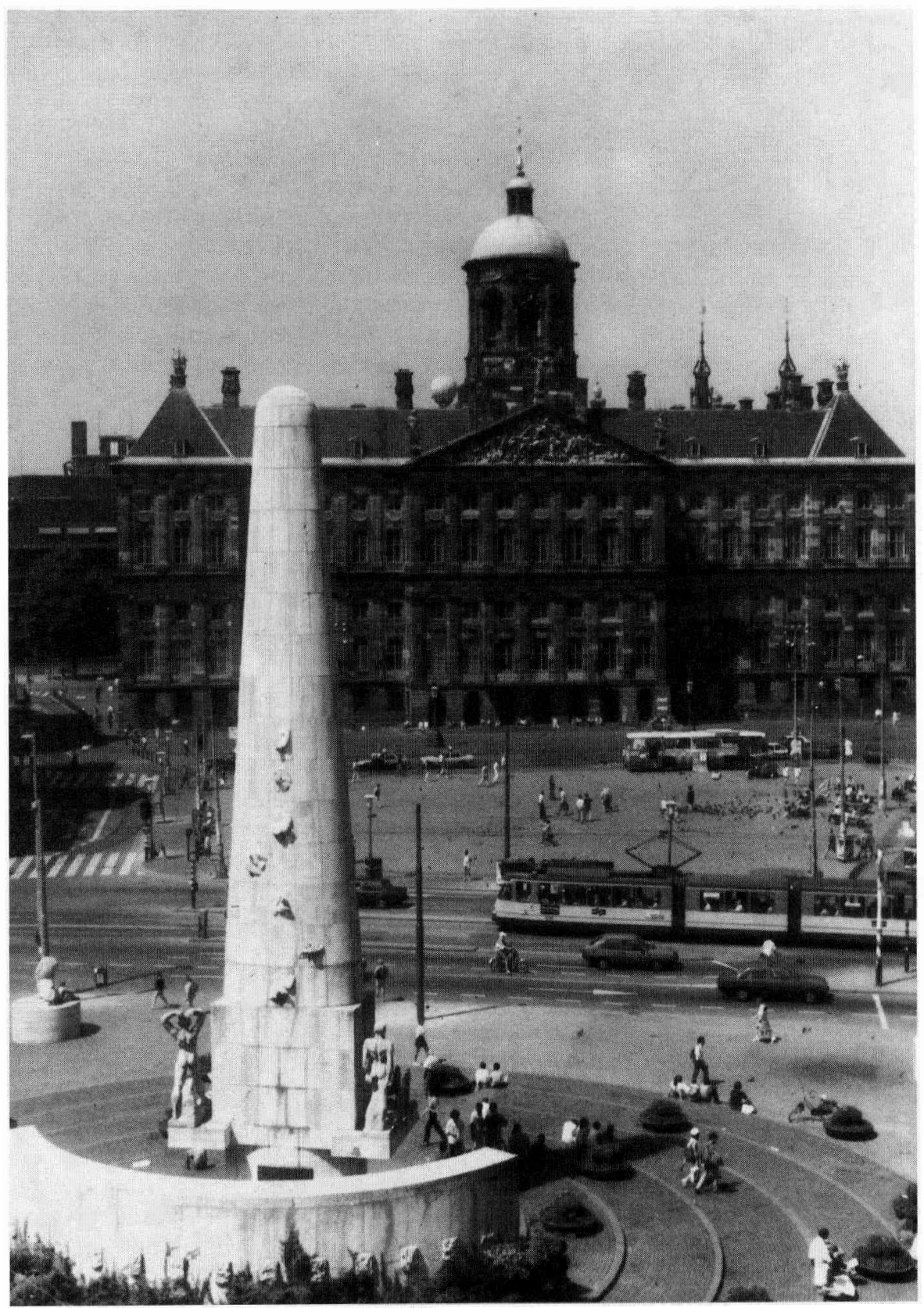

3 Het Nationaal monument op de Dam. 


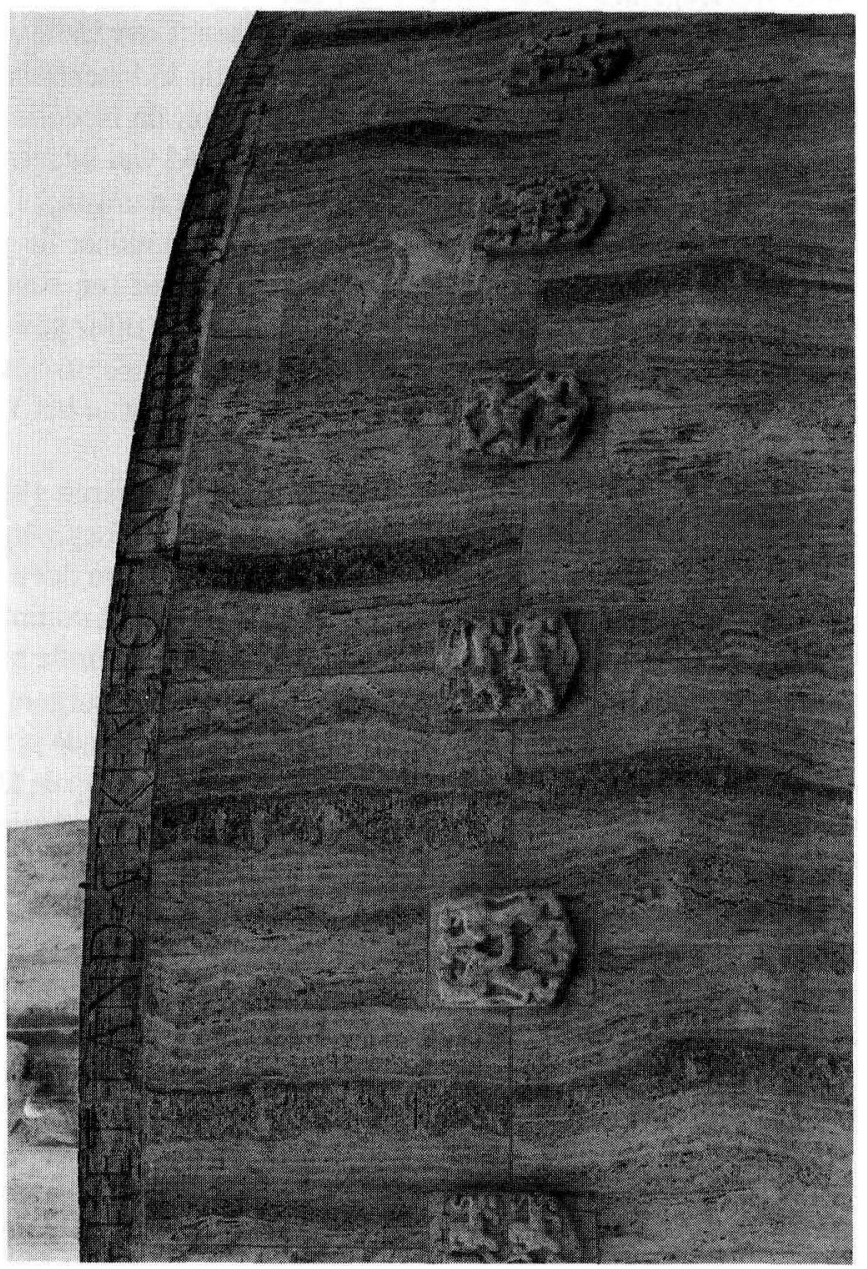

4 De steen met het Nederlandse wapen (derde steen van rechts), waarachter de Indonesische urn werd ingemetseld (1956). 
in een gemenebest. Deze verwijzing was de enige toespeling op het pijnlijke proces van dekolonisatie ${ }^{35}$.

De Indonesische urn werd met de Nederlandse urnen ingemetseld in de achterwand van het monument, waarin 14 nissen waren uitgespaard. De ruimten voor Suriname en de Antillen bleven leeg; daar waren initiatieven niet van de grond gekomen. Stenen met de provinciale wapens verhulden de inhoud der nissen. Daar Indië als deel van het koninkrijk nooit een eigen wapen had bezeten, werd de Indonesische urn - de tiende van links - verborgen achter het nationale symbool, de Nederlandse leeuw met zwaard en pijlenbundel ${ }^{36}$. Daarmee was de hoogste graad van integratie bereikt. Het grote publiek zou de specifieke inhoud achter de wapens nauwelijks herkennen. Een restant van de beperkte opzet uit 1947 bleef echter behouden: de tekst op de muur. Alsof de Indonesische urn nooit was toegevoegd, stond (en staat) hier nog steeds de tekst van Jan Donkersloot uit 1947: 'Aarde door het offer gewijd, samengebracht uit gans het land, teken tot in verren tijd van heugenis en vaste band ${ }^{37}$. Wapensteen noch gedicht zijn onderwerp van discussie geweest in het Werkcomité Nationaal Monument of onder de gerepatrieerden ${ }^{38}$.

In de jaren vijftig bleef de scheiding in de herinnering aan de jaren 1941-1945 en 1945-1949 gehandhaafd. Medio jaren vijftig deden het Veteranen Legioen Nederland en het ministerie van Defensie pogingen om de twee lege nissen te doen vullen met urnen met aarde uit Korea en van het graf van generaal S. H. Spoor, commandant van het leger in Indië van 1946 tot 1949. Beide liepen dood op de neutrale houding van het verantwoordelijke comité onder leiding van de Amsterdamse burgemeester A. J. d' Ailly. Het monument was uitsluitend bestemd voor slachtoffers uit de periode 1940$1945^{39}$. Pas vanaf 1961 wordt de nationale herdenkingsplechtigheid op de Dam gehouden ter nagedachtenis van 'allen die sinds mei 1940 voor het vaderland zijn gevallen', inclusief degenen die in Indië het leven lieten ${ }^{40}$.

De geschiedenis van de Indonesische urn illustreert de frictie tussen de herinneringen aan de oorlog in Europa en die in Azië, alsmede het conflict tussen het naoorlogse verlangen naar eenheid en consensus enerzijds, de realiteit van de politieke tegenstellingen anderzijds. De dekolonisatie gaf het herinneringsbeleid ten aanzien van de oorlog in Azië mede vorm; politiek bepaalde de politics of memory. Oorlogsherinneringen uit de Pacific konden pas een plaats vinden toen rond de soevereiniteits-

35 Nibeg-orgaan, XI (11 mei 1956) ix, 69.

36 D. Rühl, Historisch overzicht van het Nederlandsche wapen en de Nederlandsche vlag (Bandoeng, 1940)65.

37 Carasso,'Nationaal Monument', 148.

38 Dat blijkt uit het archief betreffende het Nationaal monument in het gemeentearchief te Amsterdam en de jaargangen van het Nibeg-orgaan.

39 Voorzitter werkcomité aan minister van Defensie, 29-7-1955 en concept antwoord februari 1956, GAA 396, map 16. Spoor was in mei 1949 plotseling gestorven en begraven op de erebegraafplaats Menteng Pulo in Jakarta. Deze verzoeken werden opnieuw ingediend en opnieuw verworpen in de jaren tachtig. Beide urnen zijn nu deel van de collectie van het Bronbeek-museum in Arnhem.

40 De Nieuwe Dag 27-12-1955, GAA 396, map 19; J. Vermolen, 'De vierde en vijfde mei: herinnering aan en herdenking van de Tweede Wereldoorlog', in: G. Aalders, e. a., ed., Oorlogsdocumentatie '40-45. Zesde jaarboek van het Rijksinstituut voor Oorlogsdocumentatie (Zutphen, 1995) 96, 105. 
overdracht een neutraal moment was aangebroken. Toen pas kon de urn als enkelvoudig symbool voor oorlogsslachtoffers uit Indië officieel op de Dam worden opgenomen. Over de pijnlijke herinneringen aan de strijd om Indië werd gezwegen ${ }^{41}$. Dit proces van nationaal 'loslaten' loste op in stilte, afgesplitst van de publieke herinnering en vergeten, totdat het aan het eind van de jaren zestig zou terugkeren in het nationaal geheugen $^{42}$. De overdracht van de Indonesische urn en de soevereiniteitsoverdracht luidden een bijna twintig jaar durende stilte over het koloniale verleden in de Nederlandse cultuur, literatuur en wetenschap in, met funeste gevolgen voor de kennis over deze periode bij een breder publiek.

Ondanks de expliciete wens alle bevolkingsgroepen, met name de Indonesische, bij de urn te betrekken, bleef dit een activiteit van Nederlanders uit Indië, ex-krijgsgevangenen, verzetslieden en vrouwelijke burgergeïnterneerden. Zij fungeerden als pressiegroep en als 'herinneraars' aan hun eigen lijden. Zij waren prominent aanwezig bij de officiële ceremonies van overdracht en plaatsing in 1949 en 1950. De uitsluiting van Indonesiërs herhaalde vooroorlogse koloniale patronen van eurocentrisme, die door de isolatie van Europeanen in de Japanse interneringskampen en de revolutie nog eens waren versterkt. Koloniaal eurocentrisme spiegelde overigens het Europacentrisme in Nederland zelf met zijn eenzijdige belangstelling voor het in Europa doorstane oorlogsleed, waarover gerepatrieerden zo geregeld klaagden. Binnen een verschillende geografische context hielden de verschillende segmenten van de bevolking in Nederland zich aan identieke gedragslijnen. Elke groepering wenste aandacht voor het eigen leed ${ }^{43}$.

In 1956 was in dit herinneringproces een rituele integratie van Indische oorlogservaringen in de nationale herinneringscultuur bereikt. De Indische groepsherinnering was opgenomen in het ultieme symbool van nationale eenheid, het Nationaal monument op de Dam. Het illustreerde de succesvolle integratie van de eerste golf van repatrianten, de koloniale elite, in de Nederlandse maatschappij. Onder invloed van de verslechterende verhouding met Indonesië immigreerden op dat moment andere groeperingen en klassen uit de Europese bevolkingsgroep in de voormalige kolonie naar Nederland ${ }^{44}$.

Alle urnen waren nu zonder onderscheid door inmetseling aan het zicht onttrokken. Dat was symbolisch, niet alleen voor het proces van integratie en assimilatie van de

\footnotetext{
41 Die vonden een uitlaatklep in een tijdelijk koloniaal activisme langs 'ethische' lijnen in het laatste restant van het voormalige koloniale rijk, Nieuw-Guinea, en in een Nederlandse verontwaardiging over het 'onbetrouwbare' gedrag van Sukamo. A. Lijphart, The trauma of decolonisation. The Dutch and West New Guinea (New Haven, Londen, 1966); Meijer, Den Haag- Djakarta, passim.

42 Voor een vergelijkbare verdringing van de herinnering aan een verloren koloniale oorlog zie Benjamin Stora, La gangrene et l'oubli. La mémoire de la guerre d'Algérie (Parijs, 1992).

43 R. Kousbroek, Het Ooslindisch kampsyndroom (Amsterdam, 1992). Europeanen in Indië hadden op hun beurt geen enkele belangstelling voor de ervaringen van voormalige verzetslieden in Nederland, die na de oorlog in Indië kwamen (mededeling van een deelneemster aan het verzet in Nederland).

44 W. Willems, L. Lucassen, ed., Het onbekende vaderland. De repatriëring van Indische Nederlanders (1946-1964) (Den Haag, 1994). In de jaren was de integratie zo volledig afgerond, dat de NIBEG als belangenorganisatie zijn functie verloor en in 1963 werd opgeheven (Nibeg-orgaan, X VIII ( 13 december 1963) xv, 145).
} 
uit Indië komenden, maar ook voor de dalende belangstelling voor de oorlog in de jaren vijftig, het decennium van wederopbouw, hard werken en zuinigheid.

\section{HET VROUWENMONUMENT IN APELDOORN/BRONBEEK}

\section{Oorlog en Indonesië aan het eind van de jaren zestig in Nederland}

In de jaren zestig keerden herinneringen aan de Tweede Wereldoorlog met nieuwe hevigheid terug in het publieke geheugen. Herinneringen aan de strijd in ZuidoostAzië volgden in hun kielzog. Stabilisering van de betrekkingen binnen Europa, de beginnende dooi in de Koude Oorlog en de groei van de verzorgingsstaat schiepen ruimte voor erkenning van verschillen in oorlogservaringen. Televisie was een belangrijk vehikel in de popularisering van de Tweede Wereldoorlog. Dr. L. de Jong presenteerde tussen 1960 en 1962 de Nederlandse oorlogservaringen in de huiskamer via zijn serie De Bezetting, door de toegankelijkheid ervan wel gekarakteriseerd als een 'waarlijk nationaal monument' ${ }^{45}$. In de tweede helft van de jaren zestig begon de naoorlogse generatie haar ouders kritische vragen te stellen over de mythe van het Nederlands verzet, over hun eigen gedrag in de oorlog en over hun onwrikbaar geloof in de Amerikaanse bondgenoot; dat laatste als gevolg van de gehate Vietnam-oorlog. In een onoverzichtelijker wereld was de oorlog met zijn duidelijke scheidslijnen van 'goed' en 'fout' een betwist moreel voorbeeld geworden ${ }^{46}$.

Deze algemene kritiek bood ruimte voor protesten tegen te eenduidige herinneringen en de verwaarlozing van specifieke verhalen, bijvoorbeeld die uit de oorlog in de Pacific. Maar ook andere factoren, zoals de verbeterde relaties met Indonesië en de grotere zichtbaarheid van het economisch snel groeiende Japan, stimuleerden deze oorlogsherinneringen. Na de overdracht van Nieuw-Guinea in 1962 keerde Indonesië terug in de Nederlandse verbeelding. Die ontwikkeling werd nog versterkt door de val van Sukarno in 1965/1966, de magneet van alle Nederlandse nationale frustraties uit de jaren veertig en vijftig. Het toerisme naar Indonesië kwam al snel daarna op gang. Tussen 1967 en 1970 maakten verschillende overeenkomsten over financiën en technische, economische en culturele samenwerking ruim baan voor hartelijker betrekkingen ${ }^{47}$. In 1971 liet de televisie zonnige beelden zien van koningin en prins op de Borobudur. Indonesië was 'in'; de nostalgie naar een Indisch paradijs uit een verloren jeugd begon aan publiciteit te winnen.

Maar het waren niet alleen verbeterde betrekkingen en nostalgie waarin Nederlandse herinneringen aan een koloniaal verleden doorklonken. Herinneringen aan de oorlog in het algemeen en Indië/Indonesië in het bijzonder gingen samen met herinneringen aan de dekolonisatie van 1945-1949. Die laatste maakten aanzienlijk meer emoties

45 Van Vree, In de schaduw, 79.

46 H. W. von der Dunk, 'Tussen welvaart en onrust. Nederland van 1955 tot 1973', Bijdragen en mededelingen betreffende de geschiedenis der Nederlanden, $\mathrm{Cl}$ (1986) 2-20,13

47 J. J. P. de Jong, 'De Nederlands-Indonesische betrekkingen 1963-1985', Internationale Spectator, XL (1986) $129-138$. 
en daarmee ook politiek debat los. In januari 1969 vestigde dr. J. Hueting, voormalig dienstplichtige in Indië, via de televisie de aandacht op oorlogsmisdaden, gepleegd door militairen in Indië tussen 1945-1949; daden die vergelijkbaar waren met Amerikaanse oorlogsmisdaden in Vietnam. De 'grote stilte' over die periode was daarmee verbroken. Het resulteerde in felle protesten van ex-militairen, een regeringsrapport, een parlementair debat en een wetenschappelijke publicatie. Toen viel de stilte opnieuw, bewijs van het selectieve karakter van de publieke herinnering en verontwaardiging ${ }^{48}$.

In dit culturele klimaat lieten zij die bij de oorlog in Zuidoost-Azië betrokken waren geweest, van zich horen. In 1967 werden de eerste grootschalige reünies van voormalige krijgsgevangenen georganiseerd, zoals de jaarlijkse Birma-reünie ${ }^{49}$. Dat waren nog besloten bijeenkomsten voor direct betrokkenen zonder veel uitstraling naar een groot publiek. Een jaar later echter nam een aantal vrouwen uit de Indische kampen het initiatief tot de oprichting van een monument. Dit monument is relevant voor dit betoog, omdat het aan het begin stond van een nieuwe ontwikkeling. Het poneerde een groepsherinnering (vernacular memory) van een Indische groepering die georganiseerd de aandacht voor het eigen leed vroeg, maar dat deed via vrij traditionele emblemen van heroïsch moederschap.

\section{Vrouwen in de kampen: een 'stille emancipatie'}

De internering van vrouwen en kinderen door Japanners had in Indië al meteen na de oorlog veel aandacht getrokken. In deze kampen had een 'stille emancipatie' plaats gevonden. Sterke persoonlijkheden hadden hier gezag uitgeoefend over kampen met soms duizenden geïnterneerden. Britse en Nederlandse officieren waren in 1945 diep onder de indruk - in gunstige of ongunstige zin — van hun krachtig optreden. Die morele en fysieke kracht werd in het algemeen toegeschreven aan hun moederrol, ook door henzelf ${ }^{50}$. Dit beeld had een vaste plaats gevonden in de (wetenschappelijke) literatuur over de kampen. Incidenteel werden deze sterke vrouwen zelfs geïdentificeerd met het Westen. Japan had weliswaar geprobeerd het Westen te kleineren 'door de vernedering van de Nederlandse vrouw', die deze aanslag met succes had weerstaan, zo schreef een man (oud-minister P. A. Kerstens) trots als inleiding bij de publicatie van een kampdagboek van een vrouw ${ }^{51}$. Het is mogelijk dat deze manlijke ver- en bewondering mede zo groot was omdat deze vrouwelijke kracht schril contrasteerde met de beelden van het dagelijks leven van Europese vrouwen in het

\footnotetext{
481945 Nederlandsch Indië, 1949 Indonesië, 1969 Achter het nieuws. Drie VARA-produkties (Hilversum, 1969) 20; J. Bank, ed., De excessennota (Den Haag, 1995); J. A. A. van Doorn, W. J. Hendrix, Ontsporing van geweld. Over het Nederlands/Indisch/Indonesisch conflict (Rotterdam, 1970). Zie voor de geschiedenis van de bronnenpublicatie over genoemde periode E. Locher-Scholten, 'Een bronnenpublicatie als signaal van koloniaal trauma? Ontstaan en ontvangst van de Officiële Bescheiden', BMGN, CXI (1996) 473-492. 49 L. van Poelgeest, 'De cabaretier en de keizer. Nederlands onverwerkte oorlogsverleden en het bezoek van de Japanse keizer Hirohito in 1971 ', Tijdschrift voor Geschiedenis, C (1987) 27-46,31. Reünies waren slechts incidenteel in tweede helft van de jaren veertig en vroege jaren vijftig georganiseerd.

50 Tekst mevrouw Luijck bij herdenkingsdienst op 10 december 1949, MINOG dossier 323. Zie ook H. Schulte Nordholt, ed., Het dagelijks leven in Indië 1937-1947. Brieven van O. Schulte Nordholt-Zielhuis (Zutphen, 1999).
}

51 De vlag moet blijven staan! M. Idenburg-v. d. Poll', Nibeg-orgaan,V (11 mei 1951) ix, 66. 
vooroorlogse Indie, die bepaald leken door sociale contacten, bedienden, tennis en liefdadigheid. Bovendien raakten deze ervaringen van vrouwen de publieke verbeelding, omdat het daarbij ging om internering van onschuldigen en zwakken.

Toen de eerste ideeën over de Indonesische urn in Indië werden gelanceerd, had het hoofdbestuur van de NIBEG in Batavia voorgesteld om de urn te vullen met aarde uit de vrouwenkampen, 'symboliserende de strijd van de vrouw in Indië'. De Indische regering had hiermee aanvankelijk ook ingestemd, maar dat plan was door de Legergravendienst terzijde geschoven ${ }^{52}$. De vrouwenkampen waren ook al snel onderwerp van film, boeken, een munt (1947) en een monument in Indonesië (1954) geworden ${ }^{53}$. Een vrouwelijke ex-geïnterneerde, Dora van Velden, had via haar dissertatie uit 1963 eerder wetenschappelijke aandacht voor de, voor een derde door vrouwen bevolkte, burgerkampen gevraagd dan manlijke ex-krijgsgevangenen voor hun internering ${ }^{54}$.

Terwijl vele vrouwen na de oorlog terugkeerden naar gezin en huishouden, bleven enkelen ook daarbuiten actief. Vrouwen uit het kamp Tjideng (Batavia/Jakarta) stichtten de door de overheid gefinancierde instelling voor sociale zorg onder Indische oorlogsslachtoffers in Indië en Nederland, de Stichting Pelita (1947) ${ }^{55}$. Bij herdenkingen en rituelen zoals de grote herdenkingsdienst die in december 1949 in Den Haag was gehouden, de overdracht van de urn in Batavia op 21 december 1949, de plaatsing van de um in het tijdelijk monument in 1950 en de onthulling van het definitieve in 1956, namen vrouwen een hoor- en zichtbare plaats in.

\section{Stichting Nederlandse Slachtoffers Japanse Vrouwenkampen}

In 1968, ruim twee decennia na de oorlog, nam een aantal echtgenotes en dochters van militairen, die geïnterneerd waren geweest in Tjideng, deze draad weer op ${ }^{56}$. Directe inspiratie vormde het gebrek aan belangstelling voor de oorlog in ZuidoostAzië bij officiële herdenkingen. Om daarvoor aandacht te vragen, stelde de nieuwe Stichting Nederlandse Slachtoffers Japanse Vrouwenkampen zich vier doelen: een reünie, een organisatie, een boek en een monument. Binnen een jaar wist men de eerste twee programmapunten te realiseren. De eerste grootschalige reünie van 6.000 tot 7.000 voormalige geïnterneerden werd in april 1969 in Den Haag gehouden. Zij was georganiseerd door de stichting en de nieuw gevormde Bond van ex-Gevangenen

52 Nota 5/3 bij A. Doup aan Legercommandant in Indonesië 11-2-1949, Algemene Secretarie 2273.

53 De film 'Vrouwenkamp Borneo', naar het boek van Agnes Newton Keith, Three came home, draaide in 1950. Nibeg-orgaan, V (10 november 1950) xxi, 329; VI (9 februari 1951) iii, 21. Het monument was opgericht op de erebegraafplaats Kalibanteng (Semarang). Nibeg-orgaan, VI (23 maart 1951) vi, 46; VI (11 mei 1951) ix, 69.

54 Zie voor de dissertatie D. van Velden, De Japanse interneringskampen voor burgers gedurende de Tweede Wereldoorlog (Franeker, 1963); E. Locher-Scholten, 'Een onbekende auteur van een beroemd boek. Dora van Velden en De Japanse burgerkampen', in: G. Aalders, e. a., ed., Oorlogsdocumentatie '40'45. Negende jaarboek van het Rijksinstituut voor Oorlogsdocumentatie (Zutphen, 1998) 242-265. Zie voor de krijgsgevangenenkampen E. van Witsen, Krijgsgevangenen in de Pacific-oorlog (Franeker, 1971 ). 55 W. Tinnemans, F. von Winckelmann, Indisch licht. Een halve eeuw steun aan oorlogsgetroffenen uit Indië (Den Haag, 1997) 29; W. C. Lemaire, '1947-1987, veertig jaar Pelita', in: 40 Jaar stichting Pelita. 'Licht op landgenoten uit de archipel' (S. 1., 1987).

56 Mevrouw J. van Kempen, voorzitster van de stichting in 1995, noemde het toeval dat dit gebeurde aan het begin van de tweede feministische golf; interview 8 februari 1995 . 
van Overzee, een voorloper van de in 1970 opgerichte Bond van ex-Geïnterneerden en Gerepatriëerden van Overzee (BEGO). Het beoogde boek De lach uit leed geboren verscheen in 1971, terwijl het monument later in datzelfde jaar werd onthuld ${ }^{57}$.

Het monument was een herdenkingsteken voor vrouwelijke oorlogsslachtoffers, en door hen georganiseerd. Overheidssubsidie was er niet aan te pas gekomen; de fondsen waren uitsluitend uit particuliere beurzen geworven. De oorspronkelijk gewenste plek in Den Haag had de stichting opgegeven, omdat het gemeentebestuur inspraak in de keuze van de ontwerper had gewenst. Op aanraden van koningin Juliana, die bij de herdenking in augustus 1970 (zie hieronder) blijk had gegeven van haar warme belangstelling voor het tentoongestelde ontwerp, had men vervolgens de gemeente Apeldoorn benaderd. Hier onthulde de koningin het monument in december 1971. Nadat het in 1984 aan vandalisme ten prooi was gevallen, werd het een jaar later in Arnhem (Bronbeek) opnieuw opgesteld ${ }^{58}$.

Het monument stond in de traditie van sterke vrouwen; het verbeeldde veeleer kracht en weerstand dan lijden. De beelden stelden een vrouw voor, de arm in protest geheven, de ander gebogen naar het kind dat tegen haar benen bij haar bescherming zocht: de protesterende en beschermende moeder. Achter haar ging een tweede vrouwenfiguur schuil zonder kind, die in wanhoop naar de lucht keek; de symbolische schaduw van de sterke moeder. Het opschrift op de sokkel 'Onversaagd en ongebroken' formuleerde eenzelfde boodschap van innerlijke kracht.

Daarmee combineerde dit monument opvattingen over verzet van karaktervolle Nederlandse vrouwen met het traditionele beeld van vrouwelijkheid bij uitstek: het moederschap. Vrouwelijke kracht werd hierdoor veeleer functioneel dan dat het traditionele ideeën over de ware vrouwelijkheid aantastte of bedreigde. Bovendien, deze representatie maakte, dat de oorlogsherinnering van vrouwen uit Indië naadloos kon aansluiten bij de nationale symbolentaal. Ook op het monument op de Dam nam immers een vrouw met kind als symbool van overwinning en bevrijding een centrale plaats in $^{59}$. De verwijzing naar het moederschap paste ook in het idioom van Nederlandse vrouwen in het algemeen en de nationale vrouwenbeweging in het bijzonder. Feministen uit de eerste feministische golf hadden hun claims voor een vrouwelijk burgerschap gelegitimeerd met een beroep op de traditionele moederrol, die niet tot het gezin beperkt mocht blijven. Deze opvattingen hadden in de oorlog ook andere vrouwen bereikt ${ }^{60}$. Het beeld van de sterke moeder verwees dus niet alleen naar de

57 De stichting was opgezet door de schrijfster Jo van Dijk-Manders, die ook het boek verzorgde; J. Manders, De lach uit leed geboren. Herinneringen uit de Japanse concentratiekampen voor vrouwen en kinderen opgespoord en gebundeld door-(Nijmegen, s.a.) gepubliceerd in januari 1971. Voor de reünie zie de grammofoonplaat 'Twintig jaar later', particulier bezit.

58 Ontwerper was Frans Nix, een voormalig kampkind. Hij zou later ook betrokken raken bij een ander vrouwenmonument, dat van kamp Ravensbrück in Amsterdam. Ramaker, Sta een ogenblik stil, 118-119. Interview met mevrouw J. van Kempen, 8 februari 1995. G. S. Vrijburg, e. a., Een ereschuld ingelost, 25 Jaar na de capitulatie van Japan: het einde van de Tweede Wereldoorlog (Den Haag, s.a. [1972]) 91.

59 Carasso, 'Nationaal monument', 22.

60 M. Schwegman, J. Withuis, 'Moederschap van springplank tot obstakel. Vrouwen, natie en burgerschap in twintigste-eeuws Nederland', in: G. Duby, M. Perrot, ed., Geschiedenis van de vrouw, V, De twintigste eeuw, F. Thébaud, ed. (Amsterdam, 1993) 557-583; M. Grever, 'Feministen en het vaderland. De historische 


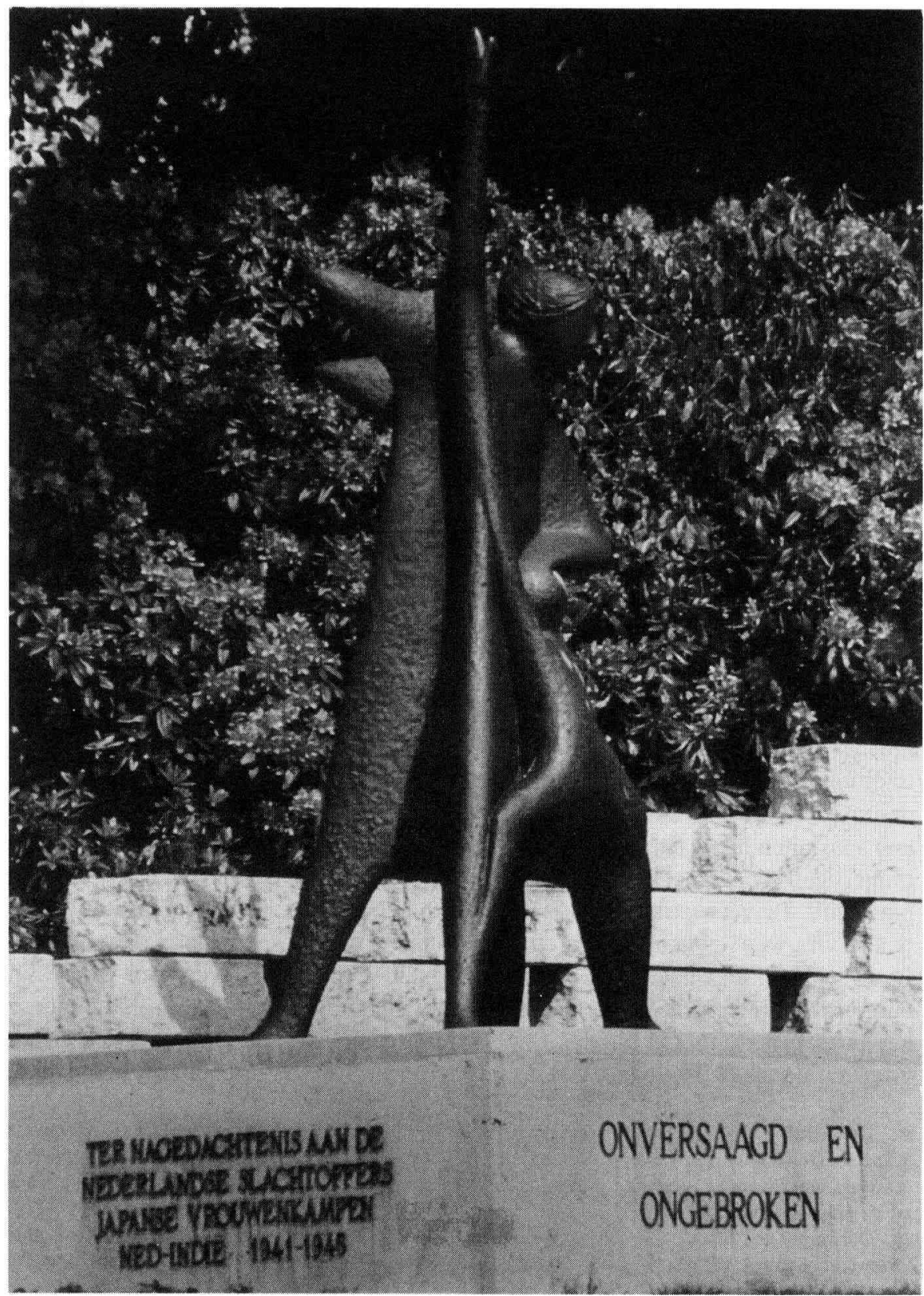

5 Het monument voor de slachtoffers van de Japanse vrouwenkampen, onthuld in 1971 in Apeldoorn, nu in 'Bronbeek', Arnhem. (Foto: Museum Bronbeek, Arnhem) 
eigen kampervaringen van vrouwen in Indië en naar bestaande naoorlogse beelden over die vrouwen, maar onderstreepte impliciet de eenheid tussen vrouwen in Indië en Nederland.

De stichting was een nieuw initiatief en alleen al daarom een breuk met het verleden. Tot op dat moment waren er geen grote reünies van (vrouwelijke) geïnterneerden gehouden; behalve een in 1960 onthuld KNIL-monument in Enschede bestond er geen ander monument voor een Indische subgroep in Nederland. Maar zowel het monument als het begeleidende boek, dat de intenties van de stichting illustreerde, leunden op traditie. Dat was zichtbaar in de presentatie van sterke vrouwen en moeders, in de heroïek waaraan dit appelleerde en aan de aandacht voor het koningshuis. De onaantastbaarheid van het koninklijk huis was in Indië vóór en in de oorlog een groot goed geweest. Ook in de jaren vijftig was zij in Nederland hoog gehouden, maar in de jaren zestig waren hierin de eerste deuken verschenen. Zo niet binnen de stichting. Het boek opende bijvoorbeeld met een brief van de voormalige koningin Wilhelmina aan ex-geïnterneerde vrouwen uit november 1945. Haar verjaardag, 31 augustus, werd de jaarlijkse herdenkingsdag van de stichting. Haar dochter koningin Juliana onthulde het monument en zou de herdenkingen nadien bijwonen ${ }^{61}$. De Indische groepsherinnering van deze vrouwen hanteerde dus ook in dit verband een nationaal, hoewel snel veranderend idioom.

Het boek, samengesteld uit de herinneringen van een groot aantal vrouwen, leverde evenals het beeld een bewijs van hun kracht in oorlogstijd. Auteur Jo Manders had de bladzijden gevuld met anekdotes over kleine en grotere heldendaden, waarbij humor blijkbaar als belangrijkste overlevingsstrategie had gefungeerd. Hoewel humor en relativeringsvermogen inderdaad een belangrijk instrument zijn in moeilijke tijden, was de kracht hiervan wel erg zwaar aangezet. Een 'en gelachen dat we hebben' domineerde soms de tekst en liet weinig ruimte voor verdriet, klachten of andere emoties. Daarmee paste het boek in het culturele klimaat van de eerste herinneringsgolf kort na de oorlog, toen 'steeds de nadruk [werd] gelegd op het humoristische, terwijl de ondervonden ellende slechts nu en dan met een enkel woord of zwijgend [werd] gememoreerd $^{\prime 62}$. Op het moment dat beeld en boek werden gerealiseerd, moest de autobiografische hausse in de herinneringsliteratuur met al zijn verhalen van pijn en verdriet nog beginnen.

Boek en monument correspondeerden nog op een ander punt. In beide werden verzet van vrouwen en moederschap met elkaar gecombineerd, een samenhang die met de ontwikkeling van de tweede feministische golf snel aan populariteit zou verliezen. In De lach uit leed geboren kwam de notie van sterke moeders ook tot uitdrukking in de ontkenning van 'gedwongen prostitutie'. Hoewel de kwestie van 'gedwongen prostitutie' in de jaren zestig al enkele malen in de publiciteit was geweest, werd hier eenvoudig ontkend dat Japanse officieren ooit in staat waren geweest om meisjes mee te

legitimatie van een vrouwelijk 'wij-gevoel", in: M. Bosch, e. a., ed., Feminisme en verbeelding. Jaarboek voor vrouwengeschiedenis, XIV (1994) 162-170.

61 Von der Dunk, 'Tussen welvaart en onrust', 10; Manders, De lach, 1.

62 Herdenkingsdienst 10 december 1949, toespraak van majoor generaal Koninklijke Nederlands-Indische Leger (KNIL) S. de Waal, in: MINOG, dossier 323. 
nemen. Dat had vrouwelijke solidariteit weten te voorkomen. Voor Sumatra klopte het, niet voor meisjes uit kampen op Midden-Java. Het boek verborg hun pijnlijke ervaringen achter de mythe van moederlijke kracht. Pas door het optreden van Koreaanse vrouwen, die hetzelfde lot hadden ondergaan, de ervaringen van vrouwen in de oorlog in voormalig Joegoslavië en een nieuwe aandacht voor sexual politics binnen het feminisme zou dit onderwerp begin jaren negentig weer in de volle openbaarheid komen ${ }^{63}$.

Zowel in het boek als in de herinneringsrituelen concentreerde de stichting zich op de ervaringen van vrouwen binnen de Japanse kampen. Andere bevolkings- of slachtoffergroepen bleven buiten beeld ${ }^{64}$. De reünie van 1969, het boek en het monument volgden de traditie van depolitisering van de herinneringen. De aandacht was uitsluitend gericht op de periode 1941-1945. Daardoor bleven boek, monument en herdenking ver van de politieke debatten van dat moment over het Nederlands (militaire) optreden in Indië na $1945^{65}$. Zelfs de continuïteit tussen de oorlog en de bloedige en chaotische naoorlogse maanden, de Bersiap-periode van september 1945 tot begin 1946, werd niet genoemd ${ }^{66}$.

Samenvattend kunnen we stellen dat het vrouwenmonument een beperkt, duidelijk omschreven doel kende: het gedenken van de slachtoffers van de kampen voor vrouwen en kinderen uit de periode 1941-1945. Deze herinnering van een subgroep uit het voormalige Indië maakte daarbij gebruik van nationaal geaccepteerde symbolen van een sterk moederschap en het door vrouwen geleide koningshuis. Hun monument markeerde het einde van een periode van stilte alsook het begin van een nieuwe fase. Daarin zouden oorlogsgetroffenen uit Indië — in navolging van een psychologisering van de zorg voor oorlogsslachtoffers in het algemeen - veeleer hun slachtofferschap claimen dan hun heldendom. Daarin zouden ook nieuwe groepen van zich laten horen ${ }^{67}$.

63 Manders, De lach, 144-148; Withuis, De jurk van de kosmonaute, 32-59. 'Gedwongen prostitutie' werd wel genoemd in het herdenkingsboek ter gelegenheid van 15 augustus 1970 uit 1972; Vrijburg, Een ereschuld ingelost, 16. Over het onderwerp was ook al in 1960 gepubliceerd; I. J. Brugmans, e. a., ed., Nederlandsch-Indië onder Japanse bezetting. Gegevens en documenten over de jaren 1942-1945 (Franeker, 1960). In aansluiting daarop had de redactie van het Nibeg-orgaan zijn bladzijden opengesteld voor anonieme verhalen van deze vrouwen uit de kampen Halmaheira (Semarang) and Ambarawa (Midden-Java). Hierop had echter niemand gereageerd (Nibeg-orgaan, XVI (25 augustus 1961 ) xix, 124). Voor het regeringsrapport zie Handelingen Tweede Kamer der Staten-Generaal, 1993-1994, no. 23607.

64 Bij de reünie van de stichting in 1969 werden alleen KNIL-militairen geprezen als voormalige beschermers. Dat strookte met de herkomst van de organiserende groep: Nederlandse vrouwen uit KNILfamilies.

65 Het jaar 1949 werd alleen impliciet genoemd in de titel van de grammofoonplaat van de reünie van 1969: 'Twintig jaar later'. Op de vraag waarom deze reünie nu pas werd georganiseerd, luidde het antwoord: 'Na twintig jaar hebben we overwonnen': Grammofoonplaat van de reünie 'Twintig jaar later', privébezit.

66 Bersiap is de kreet, waarmee jonge Indonesische revolutionairen elkaar aanspoorden: wees gereed.

67 I. de Haan, Na de ondergang. De herinnering aan de jodenvervolging in 'Nederland 1945-1995 (Den Haag, 1997). 


\section{HET INDISCHE MONUMENT IN DEN HAAG}

\section{De jaren tachtig: het decennium van de herdenkingen}

In de jaren tachtig groeide de belangstelling voor de Tweede Wereldoorlog. Nieuwe onderwerpen op de politieke agenda zoals mensenrechten deden omzien naar verschijnselen als racisme en discriminatie in het verleden. 'De oorlog' was nu onlosmakelijk deel van de Nederlandse cultuur geworden. Kinderen werden er op al de basisschool mee geconfronteerd en kwamen er door kinderliteratuur of via televisieprogramma's mee in aanraking. In het beginnend ik-tijdperk vonden persoonlijke documenten uit de oorlog, zoals het indrukwekkende dagboek van Etty Hillesum, een snel groeiende lezerskring; zij voorzagen de oorlog van een menselijk gezicht. De wetenschappelijke debatten verschoven van de sterk moralistische beoordeling van 'goed' en 'fout' tijdens de bezetting naar de vele nuances van grijs daartussenin en naar lokale ervaringen tijdens de oorlog ${ }^{68}$.

Ook kwam in dit decennium de reeds bestaande trend de oorlog te 'psychologiseren' verder tot ontwikkeling. De culturele revolutie van het einde van de jaren zestig had een 'emancipatie van de emotie' gebracht, de individuele pijn had nieuwswaarde gekregen. In de jaren zeventig was immateriële, psychologische hulp voor oorlogsgetroffenen via wetgeving van de grond gekomen. Vanaf 1973 bouwde de overheid via de Wet Uitkeringen Vervolgden (WUV) haar zorg voor oorlogsgetroffenen uit. In dat jaar werd ook het Centrum ' 45 voor de psychiatrische behandeling van oorlogstrauma's geopend. De WUV werd gevolgd door de oprichting door een van overheidswege gesubsidieerd Centrum voor Informatie, Coördinatie en Dienstverlening aan Oorlogsgetroffenen in 1980, de Wet Uitkeringen Burgeroorlogsgetroffenen (1984) en de Wet Indisch Verzet (1986). In toenemende mate werden de effecten van oorlog en internering in psychologische termen geduid. Deze psychologisering van de oorlog betrof ook hen die de oorlog in Zuidoost-Azië hadden meegemaakt, van wie verhoudingsgewijs een groot aantal getraumatiseerd was ${ }^{69}$. Een 'gedeeld slachtofferschap' opende nieuwe mogelijkheden voor publieke her- en erkenning.

\section{Herinneringen aan de oorlog in Zuidoost-Azië in de jaren tachtig}

Herinneringen aan de oorlog in Zuidoost-Azië volgden de algemene herleving van oorlogsherinneringen ${ }^{70}$. In oktober 1971 had het officieuze bezoek van keizer Hirohito

\footnotetext{
68 J. C. H. Blom, In de ban van goed en fout? Wetenschappelijke geschiedschrijving over de bezettingstijd in Nederland (Amsterdam, 1983); Bank, Oorlogsverleden, 4.

69 I. Bramsen, The long-term psychological adjustment of World War II survivors in the Netherlands (Delft, 1995); G. T. M. Mooren, R. J. Kleber, Gezondheid en herinneringen aan de oorlogsjaren van Indische jeugdige oorlogsgetroffenen. Een empirisch onderzoek (Utrecht, 1996) 223. De groei van de Indische clientèle is terug te vinden in de jaarverslagen van ICODO 1978-1990, Utrecht.

70 Van Poelgeest, 'De cabaretier en de keizer'. Ook de gijzelingen van twee treinen door Molukse jongeren in 1975 en 1977 brachten het koloniaal verleden slechts tijdelijk terug in de publieke herinnering; zie R. Barker, Niet hier maar op een andere plaats. De gijzelingen van Wijster, Amsterdam, De Punt en Bovensmilde (Alphen aan den Rijn, 1988).
} 
aan Nederland dankzij de kritische actie van de populaire cabaretier Wim Kan even de aandacht getrokken, maar daarna was het weer stil geworden op dit front ${ }^{71}$. In Nederlandse ogen was Indonesië nog steeds het meest populaire ontwikkelingsland ter wereld, dat met India wedijverde om een eerste plaats als ontvanger van Nederlandse ontwikkelingsgelden. Als toeristische attractie bood het Nederlanders de mogelijkheid tot bezoek aan het land van herkomst. De Indonesische houding tegenover de mensenrechten wierp in dit decennium nog maar een vage schaduw op de betrekkingen tussen beide landen. De historische banden wogen zwaarder.

De populariteit van Indonesië was ook terug te vinden in de literatuur, zoals in memoires over de oorlog. Tussen 1945 en 1950 waren er 18 herinneringen en dagboeken over de oorlog in Indië gepubliceerd, gevolgd door 15 in de twintig jaren van 'stilte' (1950-1970). In de jaren zeventig vond een lichte versnelling plaats (19 in tien jaar), gevolgd door een hausse in de jaren tachtig ( 80 publicaties $)^{72}$. Deze publicaties beantwoorden aan de vraag van de Indische groep zelf. De jongere generatie daarbuiten raakte nauwelijks beter geïnformeerd over wat er in Indië was gebeurd. In kinderliteratuur kwam het thema niet voor. Middelbare scholieren moesten tot de jaren negentig wachten voordat populaire schrijvers dit onderwerp op de boeken voor de eindexamenlijsten deden belanden ${ }^{73}$.

Historische publicaties over Indië/Indonesië uit de jaren tachtig ondergingen eenzelfde lot. De groeiende kennis over oorlog en revolutie bereikte zelden een breed publiek. Alleen deel Xla van De Jongs Het koninkrijk der Nederlanden in de Tweede Wereldoorlog, dat de geschiedenis van Nederlands-Indië vóór 1942 behandelde, wist in 1984 algemene aandacht te trekken. Zijn kritiek op 'de mythe van het goede bestuur' resulteerde in een rechtszaak, aangespannen door een aantal Indische organisaties ${ }^{74}$. Drie jaar later wist De Jong zich nog eens van hun woede te verzekeren, toen het concept van deel XII over de dekolonisatie aan de pers werd doorgegeven. Zijn uitspraak over oorlogsmisdaden deed het tweede publieke debat over dit onderwerp ontvlammen. Zijn deel Xlb over de oorlogservaringen zelf was echter door diezelfde Indische groeperingen met groot enthousiasme ontvangen; dankzij zijn uitgebreide beschrijvingen van het leven en lijden in de kampen werd dit deel als een bijbel voor hen die het Japans bewind hadden doorstaan.

In de jaren tachtig ontstond ook een 'nieuwe' traditie: de jaarlijkse herdenking van het einde van de oorlog in de Pacific op 15 augustus. Die datum was in de jaren veer-

71 Van Poelgeest, 'De cabaretier en de keizer', 27-46.

72 E. Captain, 'Herinneringen uit gescheiden werelden. Kampliteratuur van vrouwen en mannen in Nederlands-Indië' (Niet gepubliceerde doctoraalscriptie, vakgroep vrouwenstudies, Universiteit Utrecht 1992)65,67.

73 Voorbeelden hiervan: J. Brouwers, Bezonken rood (Amsterdam, 1981); A. van Dis, Indische duinen (Amsterdam, 1994); F. Springer, Bandoeng, Bandung (Amsterdam, 1993).

74 R. Boekholt, De staat, dr. L. de Jong en Indië: het proces van het Comité Geschiedkundig Eerherstel Nederlands-Indië tegen de Staat der Nederlanden (Den Haag, 1992). Het was de enige ernstige kritiek op de 13-delige serie. Zie P. Romijn, 'Myth and understanding. Recent controversy about Dutch historiography on the Netherlands-Indonesian conflict', in: R. S. Kirsner, ed., The Low Countries and beyond (New York, Londen, 1993)219-229. 
tig in eigen kring herdacht, maar in de jaren vijftig en zestig vergeten. Het was een lustrum, altijd gunstig voor de 'herinneringsindustrie', dat de datum opnieuw in het collectieve bewustzijn bracht. Na de grote herdenking van de 25 -jarige bevrijding in mei 1970, was er op 15 augustus van dat jaar voor het eerst een uitgebreide 'eenmalige' herdenking van het einde van de oorlog in Azië gehouden ${ }^{75}$. Deze beantwoordde onmiskenbaar aan een behoefte, want zij werd bijgewoond door 10.000 mensen, inclusief het koninklijk huis en vertegenwoordigers van de regering ${ }^{76}$.

De deelnemers moesten een tiental jaren wachten voordat deze herdenking herhaald werd. In de herinneringscultuur van de jaren tachtig vond institutionalisering van deze gebeurtenis plaats door de oprichting van de Stichting 15 augustus 1945, bestaande uit 24 (later 48) Indische organisaties. Deze stichting organiseerde de herdenking van 1980, bijgewoond door 11.000 personen, het koninklijk paar, leden van de regering en de Indonesische ambassadeur. Want ook Indonesiërs werden herdacht. Toch lag het accent op de oorlogservaringen van Europeanen in de Pacific. In hun toespraken formuleerden sprekers zoals prof. dr. N. Beets, zelf oorlogsgetroffene, en de bekende psychiater prof. dr. J. Bastiaans van Centrum ' 45 als het ware het programma voor de jaren tachtig. Sprekers erkenden de psychologische beschadiging ten gevolge van de oorlog en riepen op tot het zoeken naar 'zelf-respect en identiteit', een identiteit gebaseerd op oorlogservaringen en verlies van het moederland. De periode 19451949 werd dus indirect gepresenteerd, als een periode van verlies zonder dat de politieke implicaties van de dekolonisatie werden benoemd. In hun bijdragen verwezen sprekers naar 'sequentiële traumatisering', de verlengde beschadiging als gevolg van oorlog én migratie ${ }^{77}$. Van de licht overtrokken heroïek van De lach uit leed geboren viel weinig meer te bespeuren.

15 Augustus 1980 was het begin van een nieuwe traditie, de jaarlijkse herdenking van de oorlog in Zuidoost-Azië ${ }^{78}$. Naast de in Nederland geboren groep uit Indië, de zogenaamde totoks, waren nu twee nieuwe groeperingen als dragers van het herinneringsproces aangetreden: Indo-europeanen of Indische Nederlanders die veelal buiten de kampen waren gebleven en zij die als kind geïnterneerd waren geweest. De laatsten waren in de jaren tachtig in psychologische problemen geraakt en hadden zich georganiseerd in de Vereniging Kinderen uit de Japanse Bezetting en de Bersiap 1941-1949 (KJBB). Indo-europeanen hadden zich verenigd in tal van sociaal-culturele

75 Vrijburg, Ereschuld, 33.

76 De publicatie met het verslag over deze dag, die in 1972 verscheen, was een uitzondering op alle hierboven genoemde patronen. Zij rapporteerde over het gehele decennium 1940-1945. Alle betrokken groeperingen werden genoemd, zowel burgers als militairen, Indonesiërs en Chinezen, mannen en vrouwen, Nederlandse militaire slachtoffers uit de periode 1945-1949 als ook hun Indonesische tegenstanders (met uitzondering van 'de extremisten'), zelfs alle 'Groot-Nederland-bouwers', Vrijburg, Ereschuld, 31.

77 Anoniem, 15 augustus 1980. Terugblik op de herdenking van het einde van de oorlog van het Koninkrijk der Nederlanden in Zuid-oost Azië tevens van de Tweede Wereldoorlog (Den Haag, 1980) 9. De term sequentiële traumatisering is van de psychiater C. Keilson, Sequentielle Traumatisierung bei Kindern (Stuttgart, 1979).

78 In 1982 vond de Japanse capitulatie ook een plaats bij de jaarlijkse herdenking van de capitulatie in Wageningen. In 1985 werd een Indische herdenkingssteen onthuld in het Nederlandse parlement. 
belangengroepen. Het snel groeiende aantal daarvan was een teken van de emancipatie van een tot dan toe stilzwijgend geassimileerde groep.

\section{Het Indisch monument in Den Haag, symbool voor een gedeeld slachtofferschap}

De plannen voor het Indisch monument in Den Haag, onthuld in 1988, maakten onlosmakelijk deel uit van de hierboven beschreven herinneringscultuur van de jaren tachtig. Anders dan men zou verwachten kwamen deze echter niet uit de koker van de Indische organisaties. Het monument was het resultaat van de samenwerking tussen het ministerie van Welzijn, Volksgezondheid en Cultuur (WVC) een een voormalig (communistisch) lid van het verzet, A. A. (Harry) Verheij. Ter gelegenheid van de veertigjarige herdenking van de bevrijding had het ministerie namelijk in 1985 een Adviescomité Oorlogsherdenkingstekens ingesteld voorde toewijzing van beschikbaar gestelde gelden. De commissie bestond uit leden die actief betrokken waren bij de herinnering aan de Tweede Wereldoorlog (het verzet, het Auschwitz-Comité en de Stichting '40-'45). Verheij was een van hen ${ }^{79}$. Hij valt te karakteriseren als een volbloed bestuurder met grote sociale capaciteiten. Na zijn deelname aan het communistisch verzet had hij carrière gemaakt in de CPN. Hij was twaalf jaar wethouder van Amsterdam geweest (1966-1978), vervolgens was hij opgetreden als voorzitter van het bestuur van het Amsterdams Medisch Centrum (AMC). Omdat er in Nederland geen Indisch monument bestond, had Verheij, in samenspraak met de hiervoor verantwoordelijke afdeling van het ministerie van WVC, al in 1985 zo'n monument in gedachten ${ }^{80}$. Verheij had geen 'Indische ervaring'. Sinds het einde van de jaren zeventig was hij echter lid van de Uitkeringsraad die moest beslissen over toekenning van uitkeringen aan oorlogsslachtoffers volgens de WUV. Behalve door de verhalen van collegae en vrienden, was hij hierdoor bij uitstek geïnformeerd geraakt over het leed dat in de oorlog in Zuidoost-Azië geleden was en de blijvende invloed ervan op de levens van betrokkenen. Er was dus een direct verband tussen de 'psychologisering' van de oorlog via de wetten en het Indisch monument. Solidariteit tussen het Nederlands verzet en de slachtoffers van de oorlog in de Pacific vormde voor Verheij een ander belangrijk motief. Hij had een monument op het oog dat zich tegen oorlog zou uitspreken, voor een groep die terzijde was komen te staan en wier geschiedenis hij had leren kennen. Een nationale herdenking kan alleen tot haar recht komen als alle lijden is herdacht, zo stelde hij in $1986^{81}$.

Verheij werd de drijvende kracht achter het Indisch monument. Een comité onder

79 Concept verslag Adviescomité Oorlogsherdenkingstekens, november 1986. Archief ministerie van VWS, Directie Verzetsdeelnemers en Vervolgden (DVV), map AO vergaderingen, AO-EB-140. De verantwoordelijke directie van het ministerie had vier projecten op het oog, een in Nederland, twee in Europa (vanuit een nationaal en een internationaal perspectief) en een in verband met de Japanse bezetting van Nederlands-Indië. Alle vier werden gerealiseerd. (AO-EB 140, ministerie VWS, DVV; ongepubliceerd rapport 'Jeugdvoorlichtingsbeleid Tweede Wereldoorlog-heden. Verantwoording en voornemens', ministerie VWS, april 1991,2.2.1).

80 Nota Ebben, ongedateerd [1985]. Ministerie van VWS/DVV, map 6.26 Adviescomité Oorlogsmonumenten. Interview A. A. Verheij, 7 februari 1995.

81 Trouw 12-8-1986. Interview Verheij, 7 februari 1995. 
zijn voorzitterschap raadpleegde de Indische organisaties. Hun positieve reacties alsook het gunstige antwoord van de minister maakten de lancering van een officiële actie door de Stichting Indisch monument mogelijk. Zij beoogde de oprichting van een monument 'in nationale stijl', een subtiele formulering; het Nationaal monument stond immers al op de Dam. De fondsenwerving getuigde van de breed gedragen instemming met dit project. Gelden kwamen van particuliere zijde en de overheid. Via de AVRO en Televizier wist de stichting leden van de Indische gemeenschap te bereiken. In een paar maanden werd hierdoor 125.000 gulden bijeen gebracht. Het verzet reageerde positief op het beroep op solidariteit. Bedrijfsleven en loterijfondsen waren een derde donor, terwijl het ministerie van WVC ten slotte elke verzamelde gulden verhoogde tot een maximum van 150.000 , ongeveer een derde van het totaal benodigde bedrag.

De brede sociale en politieke erkenning voor een Indisch monument kwam ook tot uiting in de samenstelling van het comité van aanbeveling. Hierin zaten onder anderen premier Ruud Lubbers, de voorzitters van de Tweede en Eerste Kamer alsook vertegenwoordigers van verzetsorganisaties. Slechts een enkele criticus - opvallend genoeg uit de Indische gemeenschap zelf- verhief zijn stem ${ }^{82}$. De Indische gemeenschap stemde echter in met de plannen.

Het monument diende herkenbaar te zijn voor ten minste vier groepen oorlogsgetroffenen: militairen, vrouwen en kinderen uit de kampen, krijgsgevangenen en Indo-europeanen die in het algemeen buiten de kampen waren gebleven. Het ontwerp mocht dan ook niet abstract zijn maar moest aan zekere traditionele en esthetische eisen voldoen. Het uiteindelijk geselecteerde ontwerp van de Nederlandse beeldhouwster Jaroslawa Dankowa (van Bulgaarse afkomst) ${ }^{83}$ toonde zeventien bronzen gestalten van verschillende leeftijden rond een baar, opgesteld voor een doorzichtiggeweven wand. Zij vertegenwoordigden de vele gezichten van het lijden, de pijn en het protest van verschillende generaties. De dood stond in het midden, de figuren aan de uiterste zijden verwezen naar de bevrijding. Hun getal liet ruimte voor persoonlijke identificatie door de bezoekers. Een beperkt aantal Indische kenmerken werden aan het ontwerp toegevoegd: een kaart van Indonesië, de tekst 'De geest overwint' en een kleine driehoekige pilaar waarop de verschillende groepen oorlogsslachtoffers waren vermeld. Hierop stond ook het doel van deze beeldgroep: teken van verdriet en strijd tegen terreur. Het monument werd bij de 15 augustus-herdenking van 1988 door koningin Beatrix onthuld. Opgesteld in de wijde glooiing van de Scheveningse Bosjes zou het een vast bedevaartsoord worden, altijd voorzien van bloemen en boeketten. Het was niet meer uitsluitend bestemd voor Nederlanders uit Indië. Bij de jaarlijkse herdenkingen werd ook de zwaarst getroffen Indonesische groep dwangarbeiders, de romusha, herdacht ${ }^{84}$.

82 R. Boekholt, 'Een monument voor Indië', Moesson (19 augustus 1988) 4-5. De auteur vroeg hierin om een Nederlands-Indisch monument ter ere van de gehele koloniale periode. Want Indië was meer dan de oorlog en erkenning van de Indische groep impliceerde meer dan erkenning van hun lijden gedurende de oorlog.

$83 \mathrm{Zij}$ overleed in februari 1999.

84 Volgens de Japanse legerofficier Miyamoto Shizui zou een miljoen Indonesische mannen en een half 


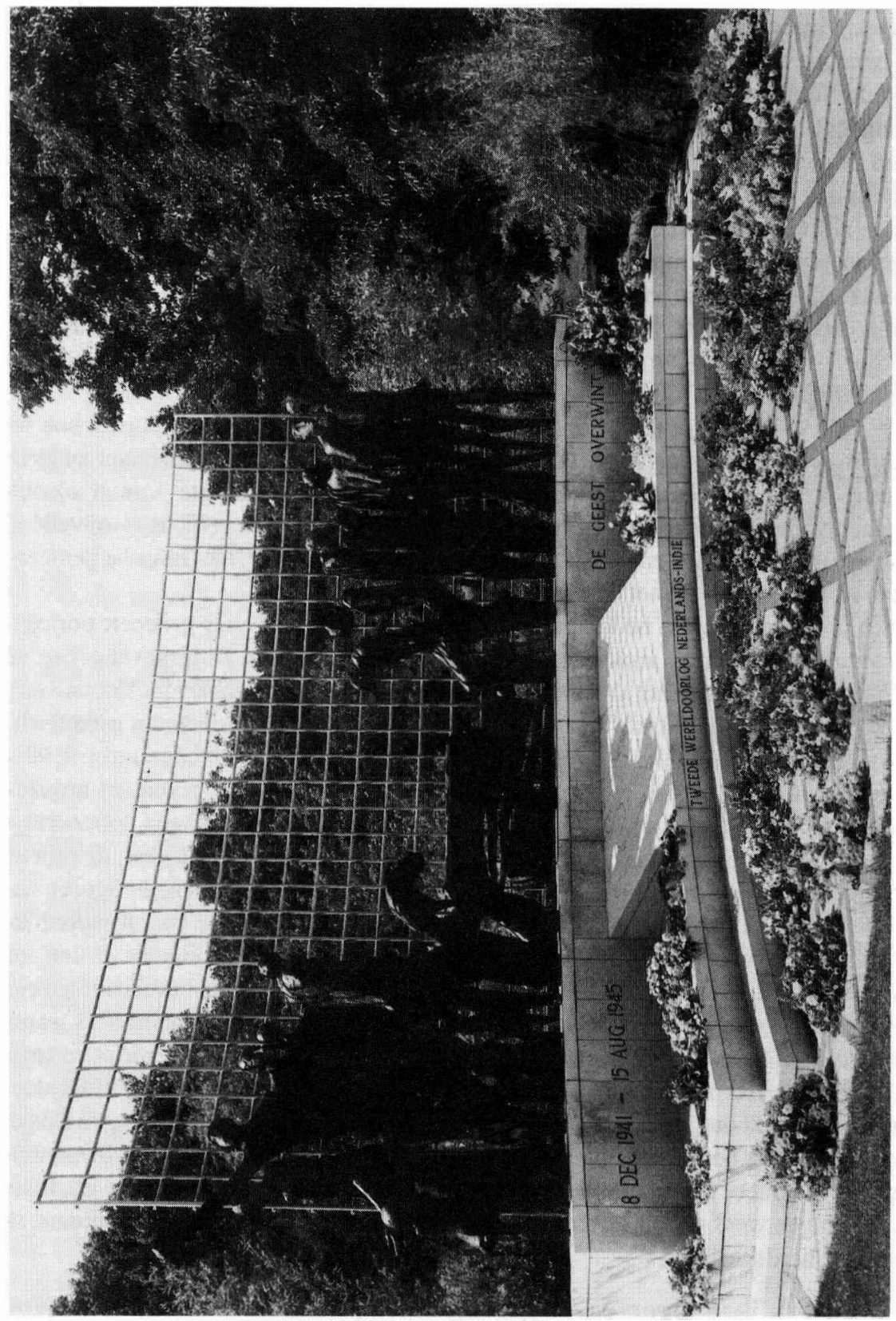

6 Het Indisch monument in de Scheveningse Bosjes, Den Haag, onthuld in 1988. 
Het monument sloot aan bij de herinneringstraditie van urn en vrouwenmonument. Vanaf het eerste moment van initiatief was het al duidelijk dat er ook hier een scheiding zou plaatsvinden van de herinneringen aan de jaren 1941 -1945 en die aan de periode 1945-1949. Dat was van de initiatiefnemer Verheij te verwachten; het sloot ook aan bij de opvattingen die op het ministerie leefden. Deze scheiding had in dit geval echter nog een andere oorzaak. Ongeveer op hetzelfde moment dat de plannen voor een Indisch monument werden ontwikkeld, namen voormalige dienstplichtigen in Roermond het initiatief voor de oprichting van een Indisch monument 1945-1949. Hun actie viel samen met de pensioengerechtigde leeftijd, die deze militairen nu (bijna) hadden bereikt. Zij paste bovendien in de hernieuwde zelf-organisatie van de veteranen, die erkenning voor hun verzwegen rol in de Nederlandse geschiedenis claimden. Een ontmoeting van beide monumentenbouwers resulteerde in het voorjaar van 1986 in een snel bereikte overeenstemming over de verschillende perioden, waarop de groeperingen zich zouden richten ${ }^{85}$. Na veertig jaar waren de herinneringen aan beide perioden nu ook in verbeelding en vorm uit elkaar gehaald.

De ontstaansgeschiedenis van het Indisch monument was er een van nationale consensus. Zij ging gepaard met een onverwacht incident, dat het Indische oorlogsverleden politieke actualiteit gaf. In december 1986 werden de voorbereidingen voor een staatsiebezoek van koningin Beatrix en prins Claus naar Japan na een kort, maar fel publiek en politiek debat stopgezet. Alle politieke partijen waren unaniem in hun sympathie voor de Indische oorlogsgetroffenen die hun 'nee' goed georganiseerd lieten horen. Het kabinet-Lubbers volgde 'gezien de bestaande gevoeligheden ${ }^{186}$. Ook in 1989 ontbrak een koninklijke vertegenwoordiging bij de begrafenis van Hirohito, nu 'op grond van de herinneringen die in onze maatschappij leven ${ }^{187}$. Daarmee bevond Nederland zich in een uitzonderingspositie. In 1986 was de Japanse keizer al door staatshoofden van alle landen waarmee Japan in oorlog was geweest, bezocht, zoals

miljoen Indonesische vrouwen gedurende de oorlog als zodanig zijn ingeschakeld. Miyamoto Shizui, 'Economie and military mobilization in Java 1944-1945', in: R. Anthony, O. Akira, ed., The Japanese experience in Indonesia. Selected memoirs of 1942-1945 (Athens, Ohio, 1986) 247. Over hun aantallen zijn historici het echter niet eens; wel over het dodental van romusha's buiten Java te werk gesteld. Dit wordt gesteld op 75\%. H. L. Zwitzer, Mannen van 10 jaar en ouder. De jongenskampen Bangkong en Kedoengdjaii 1944-1945 (Franeker, 1995) 52-53.

85 J. W. M. Schulten, 'Het afgeschreven leger. De Indiè-veteranen en hun strijd om erkenning', in: G. Teitler, J. Hoffenaar, ed., De Politionele Acties. Afwikkeling en verwerking (Amsterdam, 1990) 91-102; Informatie Stichting Nationaal Indië Monument 1945-1962. De eerste berichten over dit monument circuleerden in december 1985; zie Stabelan, XII (9 december 1985) ii, 19; Madjoe, LXIX (1985) xi, 4. 86 Antwoord minister-president, Handelingen der Staten-Generaal. Tweede Kamer, 1986-1987, appendix no. 227, 453. Zie de analyse van de publieke opinie in Algemeen Dagblad, 6 december 1986. De drie grootste politieke partijen van dat moment PvdA, CDA en VVD waren tegenstanders van het staatsbezoek. Van de geïnterviewden uit de leeftijdsgroep van 50 jaar en ouder, was $70 \%$ die mening toegedaan. Zie ook Trouw, 5 december 1986. Deze publieke schermutseling volgde kort op een ander oorlogsdebat, over het pensioen van de weduwe van de voormalige nationaal-socialistische leider Rost van Tonningen. De Japanse reacties bleven vrij koel. De Asahi Shimbun van 13 december 1986 schreef dat terwijl Japan de neiging had de oorlog te vergeten, andere landen de wreedheden van de Japanse troepen goed vasthielden: 'Nederland valt op als land waar dit nimmer vergeten wordt'.

87 Handelingen der Staten-Generaal. Eerste Kamer 1988-1989, appendix 12 
koningin Elizabeth, president Ronald Reagan, zelfs door de hoogste gezagsdragers van China and Korea. In 1989 was de officiële vertegenwoordiging bij de keizerlijke begrafenis nergens onderwerp van heftiger debat dan in Nederland ${ }^{88}$. De meeste voormalige vijanden stuurden hun staatshoofd, Nederland koos voor een lagere afgezant, de minister van Buitenlandse Zaken ${ }^{89}$. Deze uitzonderingspositie had een eenvoudige verklaring in het uitzonderlijke grote aantal Nederlanders dat tijdens de oorlog door Japan was geïnterneerd. Tachtig procent van alle geïnterneerden gedurende de oorlog in de Pacific was in Indië te vinden geweest. De groep gerepatrieerden was bovendien relatief groter dan elders (300.000 op een totale bevolking van 15 miljoen) en had door organisatie en emancipatie een krachtiger politieke stem gekregen.

Al met al kunnen we concluderen dat het Nederlandse publiek zich in de jaren tachtig in toenemende mate bewust werd van de oorlogservaringen uit de Pacific, al zou de kennis hiervan nooit de bekendheid van de Tweede Wereldoorlog in Europa evenaren ${ }^{90}$. De Indische gemeenschap wist zich in de nationale en de internationale politiek te doen horen en bereikte een hogere graad van zichtbaarheid via het Indisch monument. Dat stond overigens niet alleen maar werd al snel gevolgd door een golf van andere monumenten van Indische groeperingen, door deze zelf opgericht in de Indische omgeving van het buiten Bronbeek (Arnhem) ${ }^{91}$. De Molukse gemeenschap verkoos overigens een Moluks museum boven een monument als herinneringsplek; het opende in 1990 in Utrecht zijn deuren. Toch bleven herdenking en herinnering vooral een activiteit voor direct betrokkenen uit Indië. Hun vele organisaties en monumenten weerspiegelden de institutionalisering van deze groepsherinnering en sloten nauw aan bij het groeiend individualisme, waarin voor het nationale maar een beperkte ruimte beschikbaar was.

Sindsdien is het herinneringsproces niet gestopt. In de jaren negentig richtte de Indische gemeenschap zich bij monde van de Stichting Japanse Ereschulden opnieuw tot Japan, nu met de vraag om erkenning van schuld en financiële genoegdoening. Het drama van de gedwongen prostitutie trok in 1992 aandacht in brede kring, ook die van de overheid die een officieel onderzoek gelastte. Maar al deze aspecten van het oorlogsverleden werden in deze jaren overschaduwd door emotionele debatten in

88 Reportage 'Met het oog op morgen', NOS 27 september 1989. Het onderwerp ontlokte ook felle discussies in Australië, de VS, Korea, Canada en Israël (ANP en diplomatieke rapporten in Buitenlandse Zaken/DOA 1988-1994, no. 181 en 182; 911.21, deel IV. Intern memorandum, 28 maart 1989, no. 51-89, Ibidem). Ironisch genoeg viel dit debat evenals in 1986 samen met een opleving in de herinneringen aan de oorlog in Europa door de vrijlating van twee Duitse oorlogsmisdadigers in januari 1989.

89 Trouw, 1 februari 1989.

90 In 1991 wist $37 \%$ van de Nederlandse bevolking van de Tweede Wereldoorlog in Indië, 70\% van de meidagen 1940. Commissie Maatschappelijke Erkenning Veteranen/Lagendijk, in Veteranen, appendix 3 : 35. In 1991 hadden twee incidenten eenzelfde informatieve betekenis. Na een kranslegging door de Japanse premier Kaifu aan het Indisch monument wierp een voormalige krijgsgevangene de krans in het water van de nabijgelegen vijver. Bij de herdenking van de Japanse capitulatie op 15 augustus 1991 raakte een ei premier Ruud Lubbers.

91 Bijvoorbeeld het Sumatra/Pakan Baroe monument (1988), het monument voor de jongenskampen Bangkong-Gedungjati (1988), het monument voor de Burmaspoorweg (1989) en het monument van het voormalige KNIL (1990). 
pers en samenleving over de periode 1945-1949. De toelating van voormalig deserteur Jan 'Poncke' Princen en de felle reacties van de veteranenorganisaties maakten dit vergeten deel van de Nederlandse geschiedenis opnieuw actueel. Maar dat proces van herinnering is een ander onderwerp ${ }^{92}$.

\section{Conclusie}

Naast het schortje van een meisje uit Indië, symbool van de wens tot assimilatie, zijn hier drie artefacten neergezet die de herinneringen aan de oorlog in de Pacific illustreren. Een verborgen en vergeten urn in het monument op de Dam - hoeveel Nederlanders weten van haar bestaan? - vertegenwoordigt de uiteindelijk volledig geslaagde integratie van deze oorlogsherinneringen in de jaren veertig en vijftig. Het beeld van een protesterende en beschermende moeder in Arnhem vormt de trotse expressie van een specifieke Indische subgroep (van geïnterneerde vrouwen) uit het begin van de jaren zeventig. Het indrukwekkende en schitterend gelegen Indisch monument in Den Haag, vrucht van politieke consensus, markeert de groeiende erkenning in de jaren tachtig en negentig voor oorlogsherinneringen uit Indië in Nederland.

In de (ontstaans)geschiedenis van deze monumenten tekent zich een duidelijke lijn af: van assimilatie (het Dam-monument) via inschrijving van de herinneringen van een subgroep in het Nederlands idioom (het vrouwenmonument) naar een nationale acceptatie van specifiek-Indische herinneringen. Terwijl voor Nederlanders in Indië in die jaren de twee perioden van oorlog en dekolonisatie onlosmakelijk verbonden waren, beïnvloedde de laatste de eerste alleen in de periode 1945-1949 zelf. Dat was de belangrijkste reden om deze herinneringen in eerste instantie verre te houden van het symbool van nationale eenheid bij uitstek, het Nationaal monument op de Dam. De splitsing in de herinnering aan beide perioden maakte integratie mogelijk. Met de inmetseling van de Indonesische urn werden herinneringen aan de pijnlijke jaren 1945-1950 het zwijgen opgelegd. Die scheiding zou gangbaar blijven en in de jaren tachtig in twee verschillende monumenten gestalte krijgen. Voor een groot publiek waren oorlogsherinneringen nu eenmaal gemakkelijker te integreren dan die aan de impopulaire periode van dekolonisatie, die eerst was vergeten en toen ter discussie gesteld.

Aan het eind van de jaren zestig had fragmentering van de nationale consensus over de Tweede Wereldoorlog nieuwe ruimte geschapen voor explicitering van herinneringen van verschillende subgroepen. Vrouwelijke geïnterneerden vormden een vroeg voorbeeld van de vele groepen die in de jaren tachtig en negentig zouden volgen en in protest tegen de uniformering van de collectieve herinnering aandacht zouden opeisen voor hun verwaarloosde verhalen.

In de volgende decennia zou de 'psychologisering' van de oorlog, de groeiende formulering van oorlogservaringen in de psychologische termen van trauma en verlies,

92 Zie bijvoorbeeld V. Houben, 'A torn soul: the Dutch public discussion on the colonial past in 1995', Indonesia (april 1997) 47-66. Dit debat over het militair optreden van Nederland in Indonesië in genoemde periode, het derde na 1969 (Hueting-affaire) en 1987 (De Jong) had eveneens popularisering van kennis ten gevolge. Wist in 1991 nog maar $31 \%$ over de Nederlandse Politionele Acties, in januari 1995 was dit $81 \%$. 
oorlogsgetroffenen uit de Pacific het voor iedereen herkenbare gezicht van slachtoffers geven. Onder hen traden nieuwe groepen 'herinneraars' naar voren: Indo-europeanen die buiten de kampen waren gebleven en voormalige 'kampkinderen'. Naast de in Nederland geborenen die in de eerste fases voor erkenning hadden gestreden, werden zij de nieuwe behartigers van hun belangen. Het Indisch monument, het direct resultaat van de herinneringshausse van de jaren tachtig, versterkte het Indische identiteitsbesef, hoorbaar tot in de nationale en de internationale politiek. Hun Indisch monument was een herdenkings- en herinneringsplek, een lieu de memoire in de letterlijke betekenis van het woord, niet in de nationale betekenis die Pierre Nora aan het begrip hecht. Het definieerde een Indische identiteit, niet een nationale, de identiteit van een subgroep, niet van een natie. Paradoxaal genoeg was de integratie van herinneringen juist gestimuleerd door de organisatie van de diverse ervaringen uit het verleden via de belangenorganisaties. Sindsdien heeft het proces van de herinnering per groep zich in Bronbeek, maar ook in lokale herdenkingen, voortgezet.

Enkele vragen blijven nog over. Wat zien we van de publieke herinnering wanneer we die bestuderen via monumenten en hun geschiedenis? Wat wordt er vergeten of buitengesloten? Monumenten, letterlijk geplaatst in de publieke ruimte, worden al te gemakkelijk met de openbare herinnering geïdentificeerd. Zoals uit de hier beschreven voorbeelden blijkt, geven zij echter alleen inzicht in de grote lijnen van die herinnering (hier de samenhang met dekolonisatie, zelf-organisatie en 'psychologisering'). Dat is onder meer te wijten aan het feit dat de oprichting ervan een minimum aan consensus vereist, al was het alleen ten behoeve van goedkeuring door de overheid en van financiële ondersteuning. Die minimum-consensus is ook vereist met het oog op de herdenkingsfunctie, die velen dient aan te spreken en ruimte dient te bieden aan meervoudige interpretaties. Daarom ook worden betwiste aspecten van het verleden gemakkelijk buiten beschouwing gelaten. Of zoals Ian Buruma heeft gesteld: 'Bij een gedenkteken kunnen ceremonie en analyse onmogelijk gecombineerd worden ${ }^{193}$. Door voorbij te gaan aan historische en politieke debatten dreigen monumenten het verleden tot een onschuldig tijdverdrijf te maken. Hier zijn bijvoorbeeld de discussie rond het oorlogsverleden van keizer Hirohito, over de aard van de Japanse interneringskampen, over visies op de nederlaag tegen Japan in 1942 niet of slechts zijdelings genoemd. Monumenten bieden dan ook slechts een enkelvoudige ingang tot de publieke herinnering van het oorlogsverleden, of zich dat nu in Europa of in de Pacific heeft afgespeeld.

93 I. Buruma, Het loon van de schuld. Herinneringen aan de oorlog in Duitsland en Japan (Amsterdam, Antwerpen, 1994) 225, 242. 


\title{
Perspectief in persgeschiedenis
}

\author{
HUUB WIJFJES
}

Besprekingsartikel naar aanleiding van:

G. Mulder, P. Koedijk, Léés die krant! Geschiedenis van het naoorlogse Parool 1945-1970 (Amsterdam: Meulenhoff, 1996, 640 blz., ISBN 902904815 8); F. van Vree, De metamorfose van een dagblad. Een journalistieke geschiedenis van de Volkskrant (Amsterdam: Meulenhoff, 1996,239 blz., ISBN 902905379 8); N. Schrama, Dagblad De Tijd 1845-1974 (KDC bronnen en studies XXXI; Nijmegen: Valkhof Pers, 1996, 668 blz., ISBN 905625011 6); G. Mulder, Wim van Norden. Portret van een courantier (Amsterdam: Meulenhoff, 1997, 135 blz., ISBN 902905563 4); W. Wennekes, e. a., Het lood voorbij. Sijthoff en de Haagsche Courant. Geschiedenis van een dagbladbedrijf (Amsterdam: Thomas Rap, 1998, 200 blz., ISBN 90 6005810 0); M. Nord, Achterwaarts. Memoires (Amsterdam: Meulenhoff, 1998, 287 blz., ISBN 902905747 5); S. van der Zee, De overkant. Mijn jaren bij Het Parool (Amsterdam: Prometheus, 1998,266 blz., ISBN 905333648 6); M. Maters, Van zachte wenk tot harde hand. Persvrijheid en persbreidel in Nederlands-Indië 1906-1942 (Dissertatie Utrecht 1998; Hilversum: Verloren, 1998, 320 blz., ISBN 906550596 2); I. Cornelissen, Raamgracht 4. Mooie jaren bij het weekblad (Amsterdam: Nijgh \& Van Ditmar, 1998, 493 blz., ISBN 90388 1392 9).

Is er revolutie uitgebroken in de persgeschiedenis ${ }^{1}$ ? Onderzoekers spreken al bijna nooit meer over persgeschiedenis; vaker over mediageschiedenis. En een groeiende vloed van beschouwende artikelen duidt op een sterke behoefte aan uitbreiding van de onderzoeksinspanning in de richting van audiovisuele en nieuwe media ${ }^{2}$. In het levendig debat klinken ook pleidooien voor een fundamentele kentering in het onderzoeksperspectief. Ten voorbeeld stelt men de ontwikkeling in tal van sociaal-wetenschappelijk en historische specialismen. Daar was men in de jaren zeventig op zoek gegaan naar herkenbare en, veelal door kwantificering, onderling vergelijkbare structuren in de geschiedenis. Sinds de jaren tachtig toont men evenwel meer interesse voor de vraag hoe zich binnen die structuren mentaliteit, stijl en inhoud vormen.

Deze tendens is reeds in de beoefening van de persgeschiedenis te zien. Pershistorici keken tot voor enkele jaren terug nog vrijwel exclusief naar de institutionele kant van de pers. Men keek naar kranten als onderneming, naar het persbeleid, naar het doen en laten van grote courantiers en naar beïnvloeding van de pers door de politiek. De laatste jaren begint men ook aandacht te krijgen voor de manier waarop en onder invloed waarvan de pers en haar samenstellers in de openbaarheid vorm en inhoud construeerden. Ook wenst men een antwoord op de vraag hoe publieksgroepen aan de media-inhoud betekenis of identiteit ontleenden. Geheel afgedaan heeft daardoor de toepassing van sociaal-wetenschappelijke methoden en communicatiemodellen. De in die wereld getoonde neiging elke gecommuniceerde betekenis op doorgaans kwantitatieve manier gelijk te schakelen, heeft sowieso nooit veel historici kunnen

1 Ik dank Remieg Aerts, Marcel Broersma, Ilja van den Broek en Hans Renders voor hun constructieve en stimulerende commentaar op een eerste versie van dit artikel.

2 Zie onder meer de bundel die onder redactie van H. B. M. Wijfies en J. C. H. Blom verscheen: Mediageschiedenis: kansen en perspectieven (Amsterdam, 1995) alsmede: H. Wijfes, 'De toekomst van de mediageschiedenis' en R. Aerts, 'Het tijdschrift als culturele factor en als historische bron' in het themanummer over media en geschiedenis in Groniek, va. 135 (december 1996). 